Prepared in cooperation with the Alabama Department of Economic and Community Affairs-Office of Water Resources

\title{
Simulation of Natural Flows in Major River Basins
} in Alabama

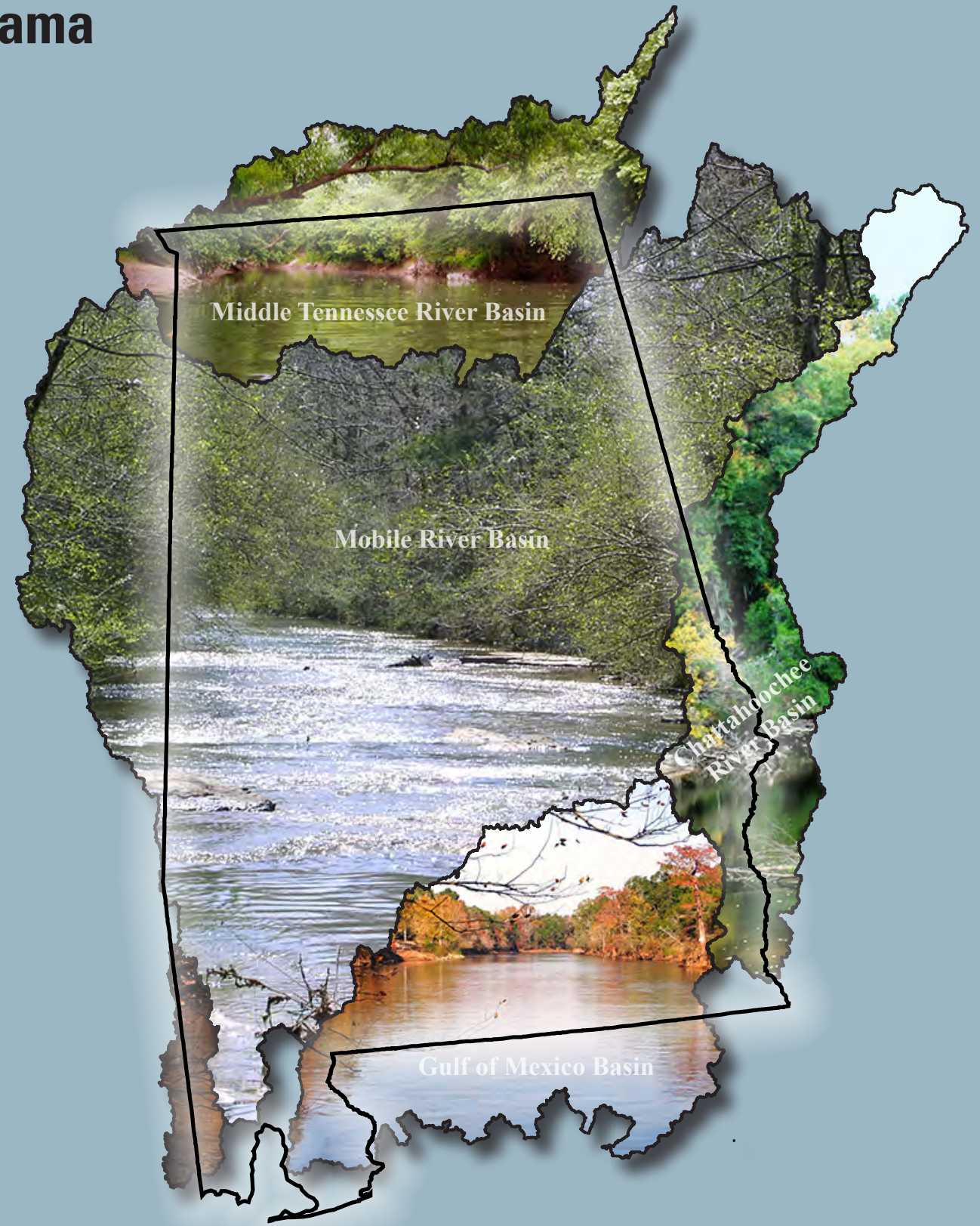

Scientific Investigations Report 2014-5021 
Cover images. River basins in the study area: Middle Tennessee River Basin (top), Paint Rock River, Jackson County; Mobile River Basin (middle), Dry Creek, Blount County; Gulf of Mexico Basin (bottom), Fork at Choctawatchee and Pea Rivers; Chattahoochee River Basin (right), Middle Fork of Cowiikee Creek, Barbour County. Photographs by Alabama Clean Water Partnership. 


\section{Simulation of Natural Flows in Major River Basins in Alabama}

By Alexandria M. Hunt and Ana María García

Prepared in cooperation with the Alabama Department of Economic and Community Affairs-Office of Water Resources

Scientific Investigations Report 2014-5021 


\title{
U.S. Department of the Interior SALLY JEWELL, Secretary
}

\section{U.S. Geological Survey Suzette M. Kimball, Acting Director}

\author{
U.S. Geological Survey, Reston, Virginia: 2014
}

For more information on the USGS - the Federal source for science about the Earth, its natural and living resources, natural hazards, and the environment, visit http://www.usgs.gov or call 1-888-ASK-USGS.

For an overview of USGS information products, including maps, imagery, and publications, visit http://www.usgs.gov/pubprod

To order this and other USGS information products, visit http://store.usgs.gov

Any use of trade, firm, or product names is for descriptive purposes only and does not imply endorsement by the U.S. Government.

Although this information product, for the most part, is in the public domain, it also may contain copyrighted materials as noted in the text. Permission to reproduce copyrighted items must be secured from the copyright owner.

Suggested citation:

Hunt, A.M., and García, A.M., 2014, Simulation of natural flows in major river basins in Alabama:

U.S. Geological Survey Scientific Investigations Report 2014-5021, 32 p., http://dx.doi.org/10.3133/sir20145021.

ISSN 2328-0328 (online) 


\section{Acknowledgments}

Numerous individuals provided support throughout this project. Lauren Hay of the USGS NRP provided PRMS expertise and processed Daily Surface Weather and Climatological Summaries (Daymet) Data. Roland Viger of the USGS NRP developed geographic information system (GIS) input files. Julie Kiang of the USGS Office of Surface Water reviewed the stations to identify undisturbed sites. Rodney Knight of the USGS Tennessee Water Science Center was the lead modeler of the Middle Tennessee River Basin PRMS model. Jacob LaFontaine of the USGS Georgia Water Science Center was the lead modeler of the Chattahoochee River Basin PRMS model. Toby Feaster of the USGS South Carolina Water Science Center and Kathryn Lee of the USGS Alabama Water Science Center provided colleague reviews of the report.

Brian Atkins of the Office of Water Resources for Alabama Department of Economic and Community Affairs provided valuable feedback, including station review and interpretation of model results. Tom Littlepage and Dow Johnston of the Office of Water Resources for Alabama Department of Economic and Community Affairs also provided valuable feedback and reviewed the models for consistency. 


\section{Contents}

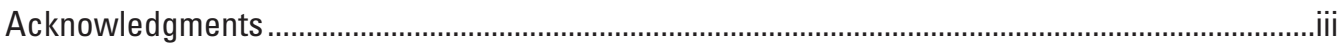

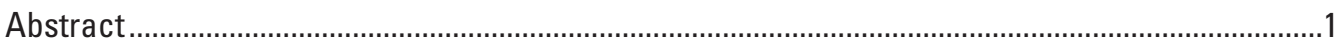

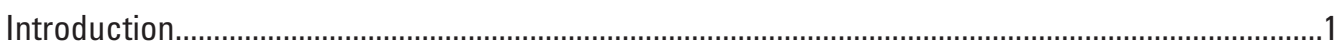

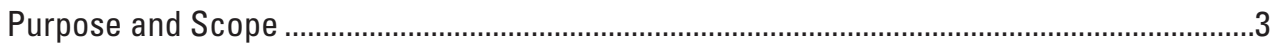

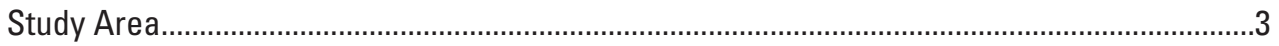

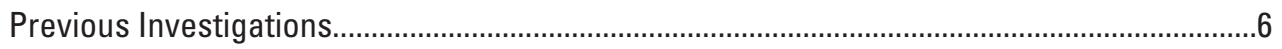

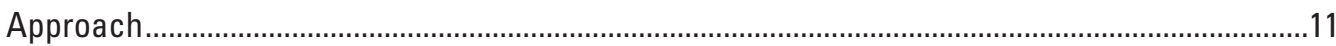

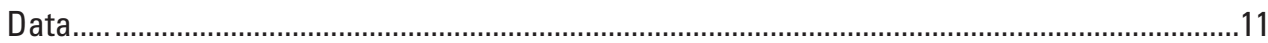

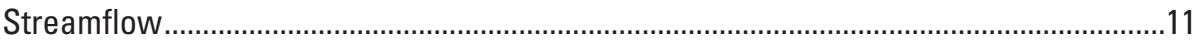

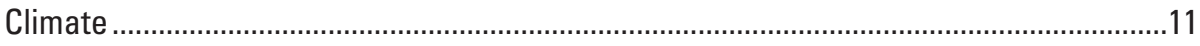

Description of the Precipitation-Runoff Modeling System Model ..........................................15

Watershed Models for Major River Basins in Alabama ...............................................................

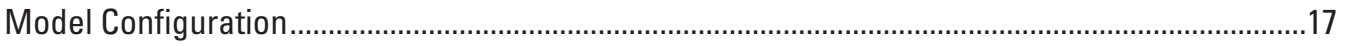

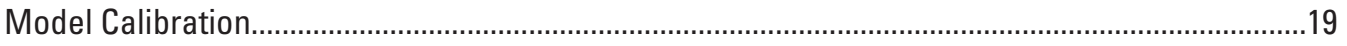

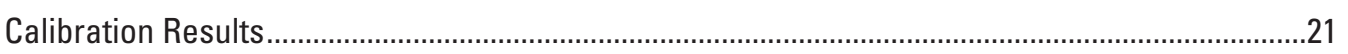

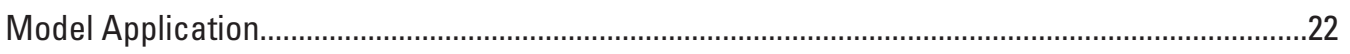

Summary.

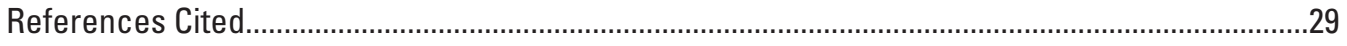

Appendix 1. Series of Graphs Presenting Model Results .............................................................31

\section{Figures}

1. Graphs showing Alabama's average annual rainfall for 1901-2012, and Alabama's average annual runoff for 1901-2012

2. Map showing location of physiographic regions in the Mobile, Chattahoochee, and Middle Tennessee River Basins and the Gulf of Mexico Basin in the Southeastern United States

3. Map showing location of ecoregions, hydrologic response units, segments, and calibration stations for the Mobile Precipitation-Runoff Modeling System model

4. Map showing location of ecoregions, hydrologic response units, segments, and calibration stations for the Gulf of Mexico Precipitation-Runoff Modeling System model

5. Map showing location of ecoregions, hydrologic response units, segments, and calibration stations for the Chattahoochee Precipitation-Runoff Modeling System model

6. Map showing location of ecoregions, hydrologic response units, segments, and calibration stations for the Middle Tennessee Precipitation-Runoff Modeling System model

7. Schematic diagram of a watershed and its climate inputs simulated by the Precipitation-Runoff Modeling System ...................................................................16

8. Illustration of the Mobile River Basin model regional calibration scheme

9. Graph showing best-fit line for simulated versus measured average monthly flow; average monthly flow; time series of daily flow; and duration curve of daily flow at the USGS station 02413000, Little Tallapoosa River at U.S. Route 27, at Carrollton, Ga.

10. Graph showing time series of daily flow, and duration curve of daily flow at the USGS station 02467000, Tombigbee River at Demopolis Lock and Dam near Coatopa, Ala. 


\section{Tables}

1. Ecoregions present in the Mobile River Basin, Gulf of Mexico Basin, Chattchoochee River Basin, and Middle Tennessee River Basin according to physiographic regions of the river basins

2. U.S. Geological Survey streamflow gages used for calibration in the Mobile River Basin Precipitation-Runoff Modeling System model..

3. U.S. Geological Survey streamflow gages used for calibration in the Gulf of Mexico Basin Precipitation-Runoff Modeling System model..

4. U.S. Geological Survey streamflow gages used for calibration in the Chattahoochee River Basin Precipitation-Runoff Modeling System model

5. U.S. Geological Survey streamflow gages used for calibration in the Middle Tennessee River Basin Precipitation-Runoff Modeling System model.....

6. Model components of the Mobile River Basin model, Gulf of Mexico Basin model, Chattahoochcee River Basin model, and the Middle Tennessee River Basin model . .17

7. Precipitation-Runoff Modeling System (PRMS) automated-calibration strategy ...........20

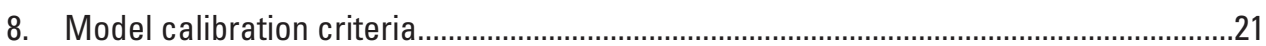

9. Precipitation-Runoff Modeling System (PRMS) model parameter sensitivity rank for flow.

10. Mobile River Basin model calibration results.................................................................23

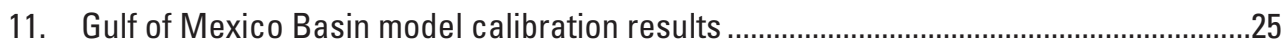

12. Chattahoochee River Basin model calibration results.....................................................26

13. Middle Tennessee River Basin model calibration results .................................................26

\section{Conversion Factors}

\begin{tabular}{|c|c|c|}
\hline Multiply & By & To obtain \\
\hline \multicolumn{3}{|c|}{ Length } \\
\hline inch (in.) & 2.54 & centimeter $(\mathrm{cm})$ \\
\hline \multicolumn{3}{|c|}{ Area } \\
\hline square mile $\left(\mathrm{mi}^{2}\right)$ & 259.0 & hectare (ha) \\
\hline square mile $\left(\mathrm{mi}^{2}\right)$ & 2.590 & square kilometer $\left(\mathrm{km}^{2}\right)$ \\
\hline \multicolumn{3}{|c|}{ Flow rate } \\
\hline cubic foot per second $\left(\mathrm{ft}^{3} / \mathrm{s}\right)$ & 0.02832 & cubic meter per second $\left(\mathrm{m}^{3} / \mathrm{s}\right)$ \\
\hline million gallons per day (Mgal/d) & 0.04381 & cubic meter per second $\left(\mathrm{m}^{3} / \mathrm{s}\right)$ \\
\hline \multicolumn{3}{|l|}{ SI to Inch/Pound } \\
\hline Multiply & By & To obtain \\
\hline \multicolumn{3}{|c|}{ Length } \\
\hline meter $(\mathrm{m})$ & 3.281 & foot $(\mathrm{ft})$ \\
\hline kilometer $(\mathrm{km})$ & 0.6214 & mile (mi) \\
\hline
\end{tabular}

Horizontal coordinate information is referenced to the North American Datum of 1983 (NAD 83). 


\section{Abbreviations}

$\begin{array}{ll}\text { ADECA } & \text { Alabama Department of Economic and Community Affairs } \\ \text { GIS } & \text { geographic information system } \\ \text { HRU } & \text { hydrologic response unit } \\ \text { HSPEXP } & \text { Hydrologic Simulation Program Expert System } \\ \text { LUCA } & \text { let us calibrate } \\ \text { NASA } & \text { National Aeronautics Space Administration } \\ \text { NED } & \text { National Elevation Dataset } \\ \text { NHD } & \text { National Hydrography Dataset } \\ \text { NLCD } & \text { National Land Cover Database } \\ \text { NRP } & \text { National Research Program } \\ \text { NSE } & \text { Nash-Sutcliffe efficiency index } \\ \text { OWR } & \text { Office of Water Resources } \\ \text { PRMS } & \text { Precipitaiton-Runoff Modeling System } \\ \text { SCE } & \text { shuffled complex evolution } \\ \text { STATSGO } & \text { State Soil Geographic } \\ \text { USACE } & \text { U.S. Army Corps of Engineers } \\ \text { USEPA } & \text { U.S. Environmental Protection Agency } \\ \text { USGS } & \text { U.S. Geological Survey }\end{array}$




\title{
Simulation of Natural Flows for Major River Basins in Alabama
}

\author{
By Alexandria M. Hunt and Ana María García
}

\section{Abstract}

The Office of Water Resources (OWR) in the Alabama Department of Economic and Community Affairs (ADECA) is charged with the assessment of the State's water resources. This study developed a watershed model for the major river basins that are within Alabama or that cross Alabama's borders, which serves as a planning tool for water-resource decisionmakers. The watershed model chosen to assess the natural amount of available water was the PrecipitationRunoff Modeling System (PRMS). Models were configured and calibrated for the following four river basins: Mobile, Gulf of Mexico, Middle Tennessee, and Chattahoochee. These models required calibrating unregulated U.S. Geological Survey (USGS) streamflow gaging stations to estimate natural flows, with emphases on low-flow calibration. The target calibration criteria required the errors be within the range of: (1) \pm 10 percent for total-streamflow volume, $(2) \pm 10$ percent for low-flow volume, (3) \pm 15 percent for high-flow volume, (4) \pm 30 percent for summer volume, and (5) above 0.5 for the correlation coefficient $\left(\mathrm{R}^{2}\right)$. Seventy-one of the 90 calibration stations in the watershed models for the four major river basins within Alabama met the target calibration criteria. Variability in the model performance can be attributed to limitations in correctly representing certain hydrologic conditions that are characterized by some of the ecoregions in Alabama. Ecoregions consisting of predominantly clayey soils and (or) low topographic relief yield less successful calibration results, whereas ecoregions consisting of loamy and sandy soils and (or) high topographic relief yield more successful calibration results. Results indicate that the model does well in hilly regions with sandy soils because of rapid surface runoff and more direct interaction with subsurface flow.

\section{Introduction}

The climate of the Southeastern United States is normally humid and subtropical, receiving moderate amounts of precipitation. However, during recent years, rainfall amounts have fallen far below average. Alabama's average annual rainfall for 1901-2012 was 54.33 inches (in.); the average annual precipitation in 2007 was 40.08 in., the third lowest annual precipitation total in the last 112 years (fig. 1) (data accessed at http://www.sercc.com/climateinfo/monthly_seasonal.html on June 25, 2013). The 30-year precipitation mean has decreased over time; for example, for 1961-1990, there was an average annual precipitation of 57.43 in., and then for 1981-2010, the average was 56.90 in. The 30 -year runoff mean has also decreased over time; for example for 1961-1990, there was an average annual runoff of 22.91 in., and then for 1981-2010, the average was 21.21 in (data accessed at http://waterwatch. usgs.gov/index.php? $r=$ al\&id=statesum on December 17, 2013). A decrease in long-term annual precipitation has substantial effects on runoff and streamflow and presents challenges for water-resource managers when trying to maintain permitted withdrawals, while also providing for instream uses of water resources and protecting water habitat.

Alabama's water-resources support a variety of uses and activities, including public water supply, residential, irrigation, livestock, agriculture, industrial, mining, and thermoelectricpower generation. During 2005, water use in Alabama was about 9,958 million gallons per day (Mgal/d) (Hutson and others, 2009). Streamflow for many of Alabama's major rivers is regulated by reservoirs, which are part of a system of navigational locks and dams.

In Section 9-10B-1 of the Alabama Water Resources Act, the Office of Water Resources (OWR) in the Alabama Department of Economic and Community Affairs (ADECA) is charged to assess the State's water resources. In order to meet this charge, the OWR was directed to determine an estimated amount of available water in the major river basins that are within Alabama or that cross Alabama's borders in the absence of hydrologic modification, such as interbasin transfers. In order to establish an estimate of water availability in the major river basins of Alabama, the different components of water use at a watershed scale need to be identified and quantified.

A well-calibrated hydrologic model of the river basins can provide decisionmakers with a planning tool whereby different scenarios of extreme climate events, land use changes, and water use can be studied. Different scenarios can be portrayed through altering major components of the hydrologic cycle processes, which include precipitation, runoff, infiltration, and groundwater recharge. These scenarios could include "what ifs," such as the impact of extreme climate events. A 

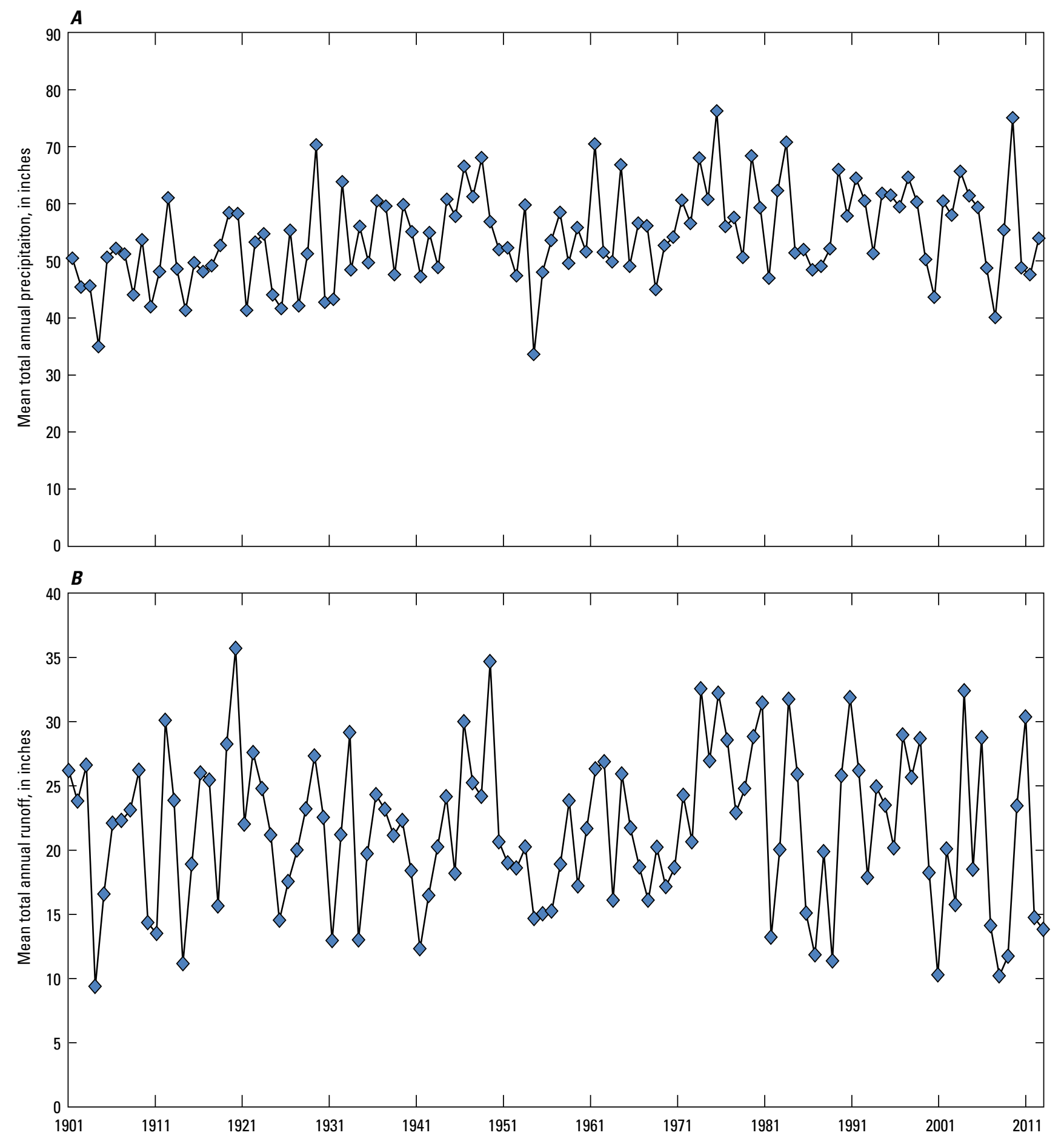

Figure 1. A, Alabama's average annual rainfall for 1901-2012. B, Alabama's average annual runoff for 1901-2012. 
natural flow model would allow water managers to quantify the baseline streamflow for a particular river. Therefore, the water managers would know the limits of water use in order to balance the societal and ecological needs.

\section{Purpose and Scope}

This report documents the configuration, calibration, and application of a hydrologic watershed model for the major river basins located within Alabama or that cross Alabama's borders. Model input files were set up with climate data that span the period from October 1, 1980, to September 30, 2008, and the model was calibrated with continuous streamflow data from October 1, 1998, to September 30, 2008.

This study addresses two of the six themes outlined in the science strategy directions of the U.S. Geological Survey (USGS): "to inform the public and decisionmakers about ... forecasts of likely outcomes for water availability, water quality, and aquatic ecosystem health caused by changes in land use and land cover, natural and engineered infrastructure, water use, and climate" and "meet the pressing needs of the Federal government, policymakers, and resource managers for state-of-the-science information and predictive understanding of climate change and its effects by studying the interactions among climate, earth surface processes, and ecosystems across space and time" (U.S. Geological Survey, 2007).

\section{Study Area}

The study area includes the following basins: Mobile River, Middle Tennessee River, Gulf of Mexico, and Chattahoochee River (fig. 2). These basins cover an area of approximately 75,000 square miles $\left(\mathrm{mi}^{2}\right)$, which encompasses most of Alabama and portions of Tennessee, Georgia, and Mississippi.

The entire study area is composed of six physiographic regions: Coastal Plain, Appalachian Plateaus, Blue Ridge, Piedmont, Valley and Ridge, and Interior Low Plateaus. The Coastal Plain is underlain by Mesozoic- and Cenozoic-age sediments and sedimentary rocks that have a low topographic relief. The Appalachian Plateaus were formed by eroded sediment from mountains and were carried westward into streams and deposited in deltas. The Blue Ridge and Piedmont are both underlain by crystalline rocks. However, the Blue Ridge is distinguished from the Piedmont primarily by greater topographic relief. The Valley and Ridge consist of a series of northeast-trending linear ridge and valleys underlain by alternating beds of hard and soft Paleozoic sedimentary rocks. The Interior Low Plateaus and the Valley and Ridge consist of similar rocks; however, the Interior Low Plateaus province lacks the folds and faults of the Valley and Ridge (Johnson and others, 2002). Each physiographic region is composed of multiple ecoregions because the framework for ecoregions subdivision considers physiography (Omernik, 1995). The U.S. Environmental Protection Agency (USEPA) level IV ecoregions denote areas that share similar ecosystems characteristics (Omernik and others, 2008).
The wide range of geologic and topographic settings leads to varying soil types for each physiographic region. The Coastal Plain is mostly dominated by poorly drained soils, such as peaty, mucky Dorovan, the sandy loam Osier, and the loamy Cahaba series. The soils formed in the valleys of the Valley and Ridge physiographic region differ from the soils formed in the ridges. The valleys are dominated by weathered limestone with silt loam surface texture. The ridges consist of cherty limestone that produces a gravelly loam and gravelly clay subsoil and a gravelly silt loam surface layer. Because the Piedmont is formed from weathering of crystalline rocks, the soil types range from clayey loamy soils to gravelly loamy soils. The Blue Ridge physiographic region varies in topographic relief and the soils tend to be moderately deep and medium textured (Johnson and others, 2002).

The Mobile River Basin (43,317 $\left.\mathrm{mi}^{2}\right)$ is mostly located in Alabama, with portions in Georgia, Tennessee, and Mississippi. The basin comprises the Tombigbee River, Alabama River, and the Mobile River. The Tombigbee River and the Alabama River meet to form the Mobile River, which drains to the Gulf of Mexico. The principal tributary to the Tombigbee River is the Black Warrior River Basin $\left(6,276 \mathrm{mi}^{2}\right)$, which has a mean annual stream flow of 9,800 cubic feet per second $\left(\mathrm{ft}^{3} / \mathrm{s}\right)$ and is about 32 percent of the mean annual stream flow from the Tombigbee River Basin (Atkins, 1998). Major tributaries to the Alabama River are the Coosa $\left(10,161 \mathrm{mi}^{2}\right)$, Tallapoosa $\left(4,675 \mathrm{mi}^{2}\right)$, and Cahaba $\left(1,825 \mathrm{mi}^{2}\right)$ Rivers. Flow is regulated with a system of locks and dams in the Alabama, Tombigbee, Black Warrior, Coosa, and Tallapoosa Rivers. Most of the unregulated streams are first-order streams located in the Coastal Plain region of the Mobile River Basin.

The Mobile River Basin is composed of five different physiographic regions: Coastal Plain, Piedmont, Valley and Ridge, Appalachian Plateaus, and the Blue Ridge (fig. 2). The central northern portion of the basin consists of the Appalachian Plateaus. The Valley and Ridge lies southeast of the Appalachian Plateaus region. Southeast of the Valley and Ridge lies the Piedmont. Towards the northeast of Appalachian Plateaus and the Valley and Ridge lies the Blue Ridge. The southern and western portions of the Mobile River Basin are located within the Coastal Plain. Table 1 denotes the ecoregions present in the Mobile River Basin, according to their physiographic region (fig. 3).

Approximately half of the Mobile River Basin is forested; the remaining land is a mix of agriculture, wetlands, and urban areas (15 percent, 7 percent, and 6 percent, respectively). Predominant agricultural activities include row crops such as cotton, corn, hay, and soybeans, as well as aquaculture, and poultry and cattle production (Atkins and others, 2004). The major urban centers in the Mobile River Basin are Birmingham, Mobile, Montgomery, and Tuscaloosa, Alabama (Ala.). Based on the 2010 U.S. Census, Birmingham metropolitan area had a population of 1,128,047; Mobile metropolitan area had a population of 412,992; Montgomery metropolitan area had a population of 374,536; and Tuscaloosa metropolitan area had a population of 221,553 (U.S. Census Bureau, 2011). 


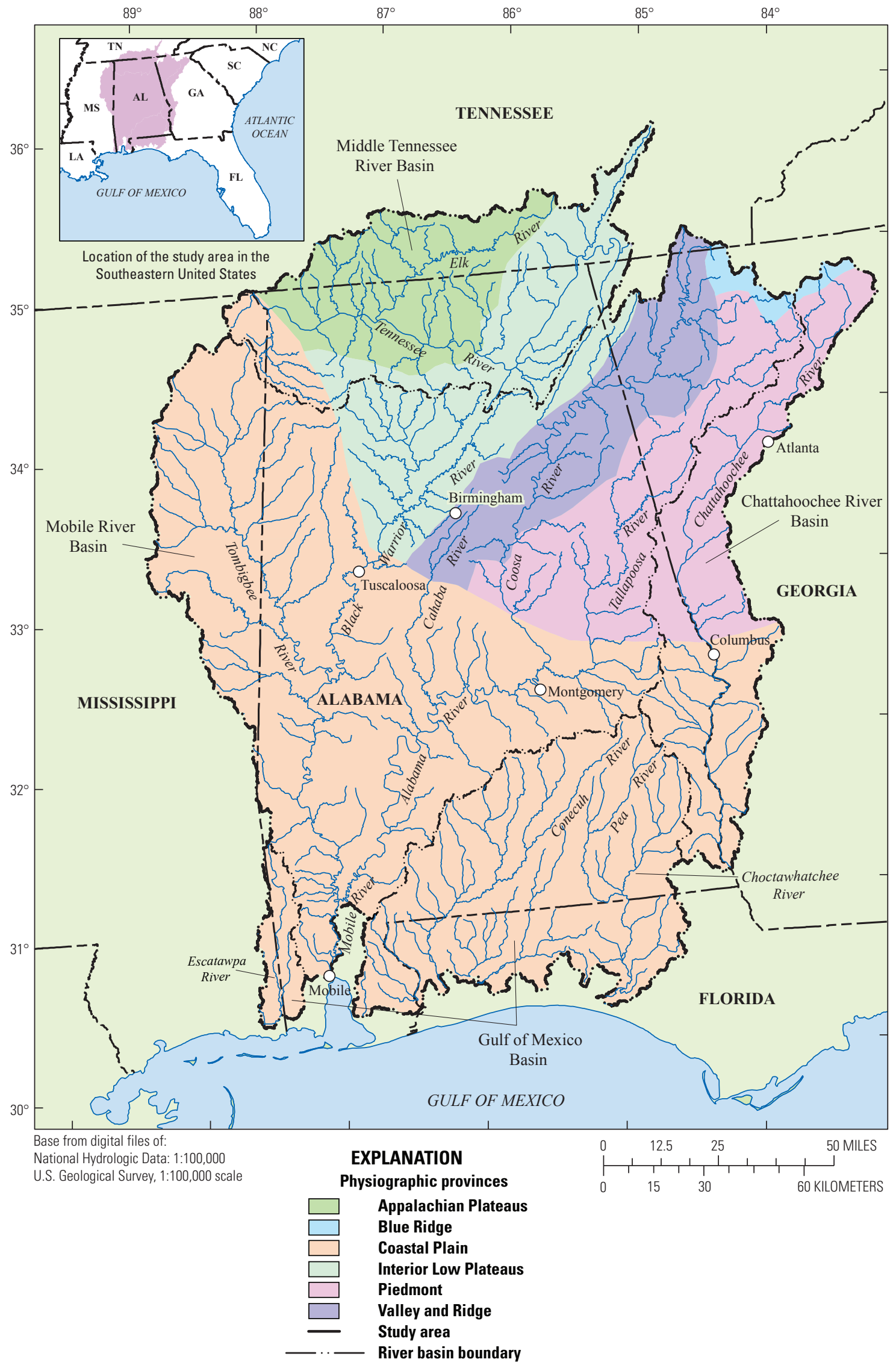

Figure 2. Location of physiographic regions in the Mobile, Chattahoochee, and Middle Tennessee River Basins and the Gulf of Mexico Basin in the Southeastern United States. 


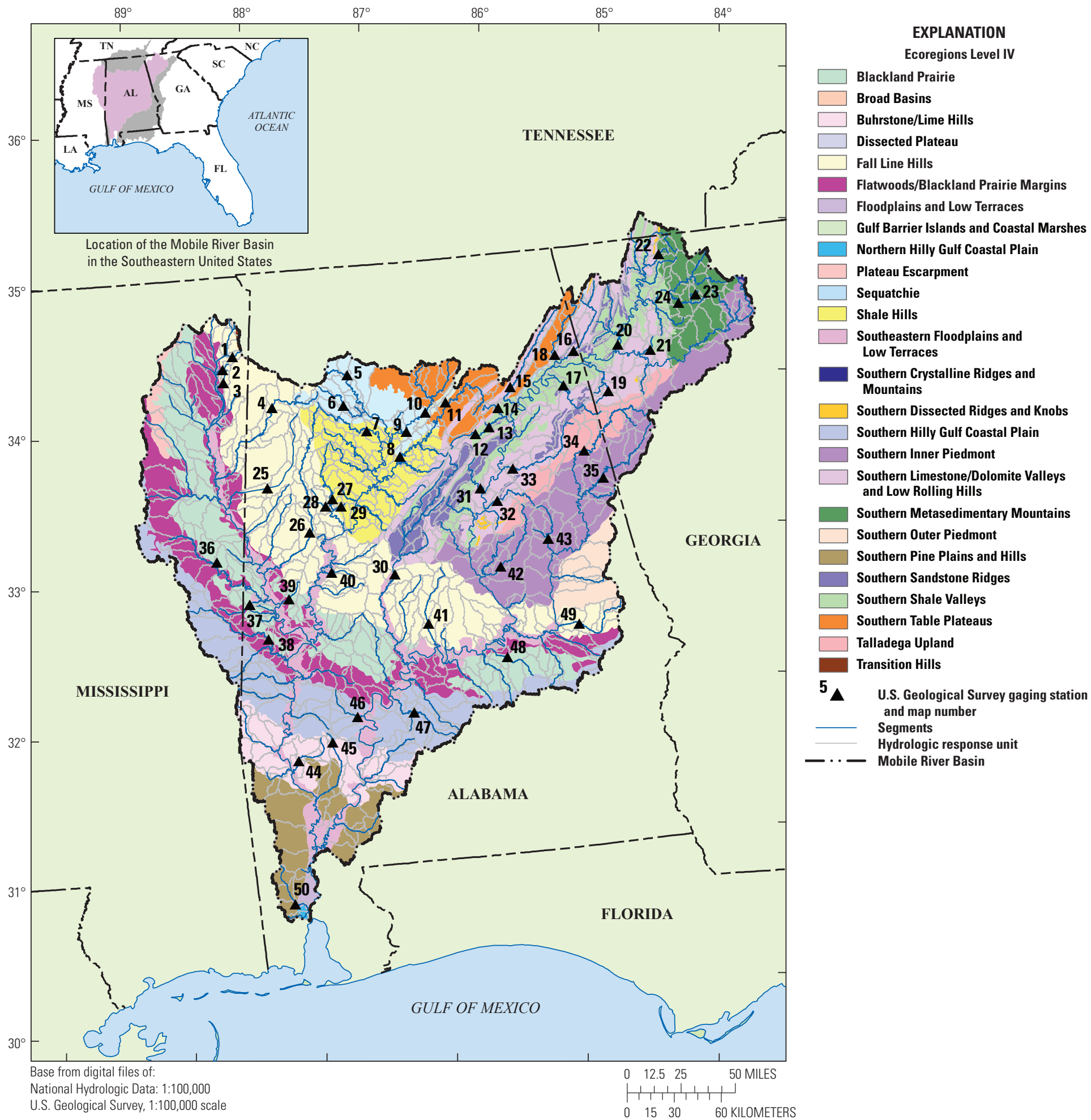

Figure 3. Location of ecoregions, hydrologic response units, segments, and calibration stations for the Mobile Precipitation-Runoff Modeling System model. 
The Gulf of Mexico Basin (13,383 $\left.\mathrm{mi}^{2}\right)$ is defined by a four-river system that drains directly into the Gulf of Mexico. These rivers are the Escatawpa River, the Conecuh River, the Choctawhatchee River, and Pea River. The Gulf of Mexico Basin is located entirely in the Coastal Plain physiographic province (fig. 2). The Coastal Plain is composed of eight different USEPA level IV ecoregions (fig. 4; table 1). Approximately 50 percent of the Gulf of Mexico Basin is forested, 17 percent is agriculture, 11 percent is wetlands, and 5 percent is urban areas. Dothan, Ala., is the largest urban center in the Gulf of Mexico Basin; Dothan metropolitan area had a population of 142,693 in 2010 (U.S. Census Bureau, 2011).

The Chattahoochee River Basin $\left(8,345 \mathrm{mi}^{2}\right)$ encompasses portions of western Georgia and eastern Alabama. This river basin is composed of three physiographic regions: Coastal Plain, Piedmont, and Blue Ridge (fig. 2). Table 1 denotes the ecoregions present in the Chattahoochee River Basin according to the physiographic region in which the ecoregions are located (fig. 5). The Chattahoochee River flows through Atlanta and Columbus, Georgia (Ga.). Based on the 2010 U.S. Census, the populations of the Atlanta and Columbus metropolitan areas were 5,268,860 and 294,865, respectively (U.S. Census Bureau, 2011). Because the Chattahoochee River flows through Atlanta, the largest metropolitan area in the Southeastern United States, the river is considered the mostly heavily used water resource in the Southeast. Twelve dams are located on the mainstem of the Chattahoochee River. Four of these dams are run by the U.S. Army Corps of Engineers (USACE) and used to regulate flow; the other eight dams are run-of-the-river dams and are not operated to regulate flow (LaFontaine and others, 2013). Approximately 45 percent of the Chattahoochee River Basin is forested, 14 percent is agricultural, 13 percent is urban, and 4 percent is wetlands. The agricultural land is mostly used for livestock grazing or poultry production.

The Middle Tennessee River Basin $\left(9,548 \mathrm{mi}^{2}\right)$ is located in northern Alabama, southern Tennessee, northeastern Mississippi, and northwestern Georgia. The Middle Tennessee River is composed of three physiographic provinces: Coastal
Plain, Interior Low Plateaus, and Appalachian Plateau (fig. 2). Table 1 denotes the ecoregions present in the Middle Tennessee River Basin, according to the physiographic region in which the ecoregions are located (fig. 6). Approximately 45 percent of the Middle Tennessee River Basin is forested, 33 percent is agriculture, 7 percent is urban, and 2 percent is wetlands. The major urban center located in the Middle Tennessee River Basin is Huntsville, Ala. Based on the 2010 U.S. Census, the population of the Huntsville metropolitan area was 417,593 (U.S. Census Bureau, 2011).

\section{Previous Investigations}

Documentation on the use and the theory that led to the development of the Precipitation-Runoff Modeling System (PRMS) model is widely available. The USGS National Research Program (NRP) hosts a site at http://wwwbrr.cr.usgs. gov/projects/SW_MoWS/PRMS.html, which links to the user manual (Markstrom and others, 2008) and various recent journal publications (Battaglin and others, 2011; Hay and others, 2011; Viger and others, 2011). The PRMS model has been used in the Southeast, including a recent application in the Apalachicola-Chattahoochee-Flint River Basin (LaFontaine and others, 2013). The Apalachicola-ChattahoocheeFlint River Basin PRMS model was developed to provide a simulation of the natural hydrologic processes of the basin in response to climate, subsurface characteristics, and land cover. Thirty-five USGS streamflow gaging stations were used for calibration in the Apalachicola-Chattahoochee-Flint River Basin PRMS model. Overall, the PRMS model for the Apalachicola-Chattahoochee-Flint River Basin provides a good representation of basin hydrology on annual and monthly time steps. The work of LaFontaine and others (2013) was part of a USGS National Climate Change and Wildlife Science Center's effort to provide integrated science that helps resource managers understand the effects of climate change on a range of ecosystem responses. 


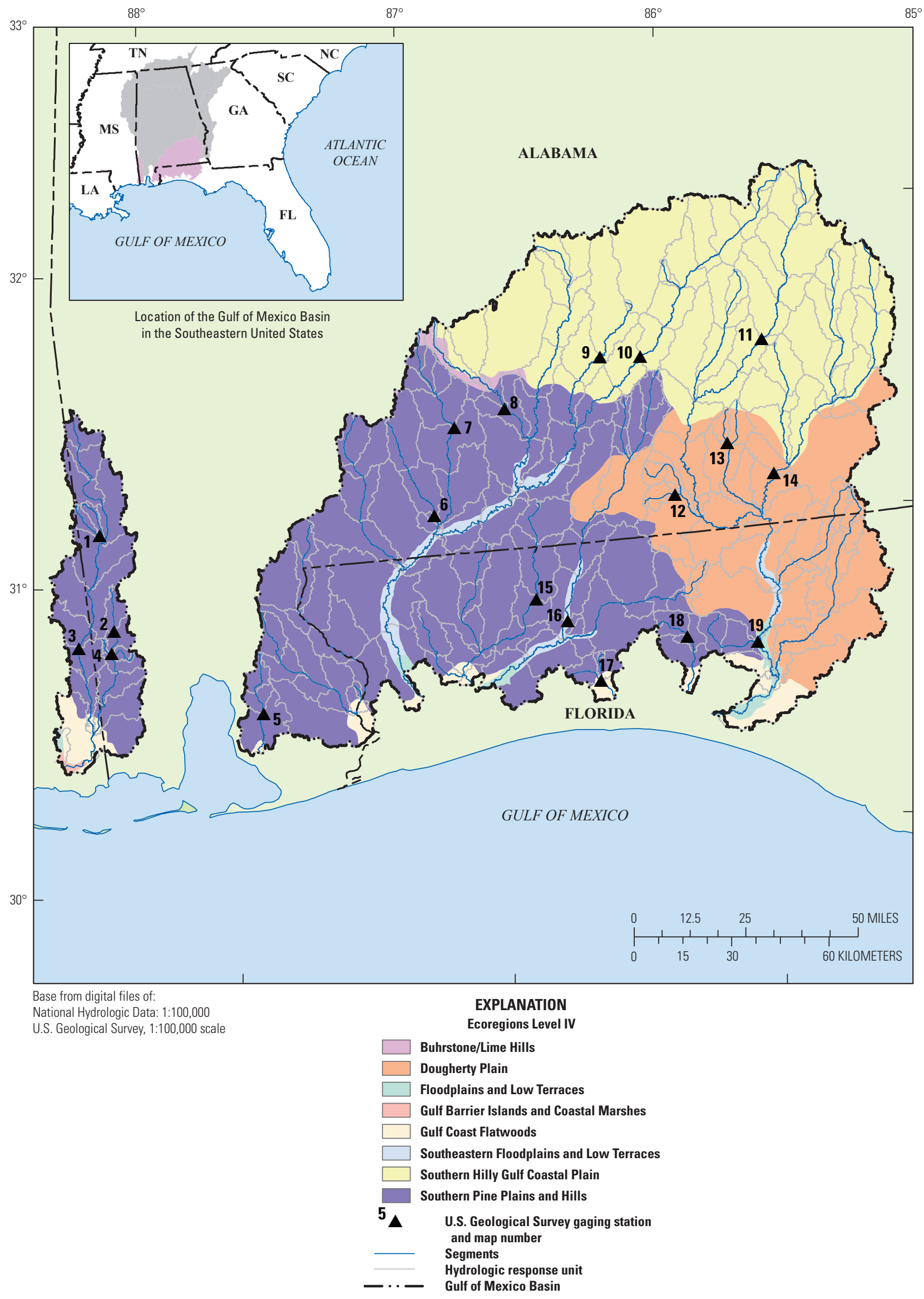

Figure 4. Location of ecoregions, hydrologic response units, segments, and calibration stations for the Gulf of Mexico Precipitation-Runoff Modeling System model. 


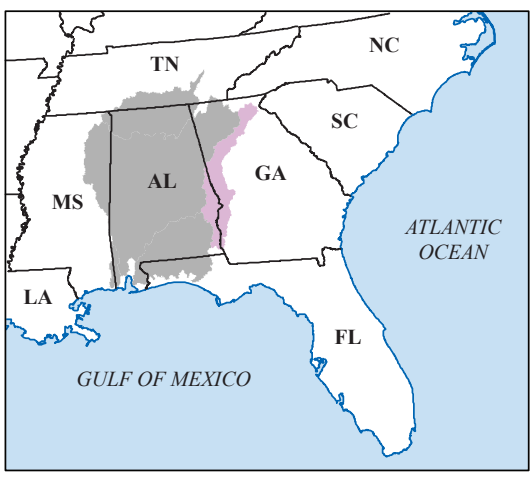

Location of the Chattahoochee River Basin in the Southeastern United States

\section{EXPLANATION}

Ecoregions Level IV

Blackland Prairie

Coastal Plain Red Uplands

Dougherty Plain

Fall Line Hills

Flatwoods/Blackland Prairie Margins

Pine Mountain Ridges

Sand Hills

Southeastern Floodplains and Low Terraces

Southern Crystalline Ridges and Mountains

Southern Hilly Gulf Coastal Plain

Southern Inner Piedmont

Southern Outer Piedmont

5 U.S. Geological Survey gaging station and map number

Segments

Hydrologic response unit

Chattahoochee River Basin

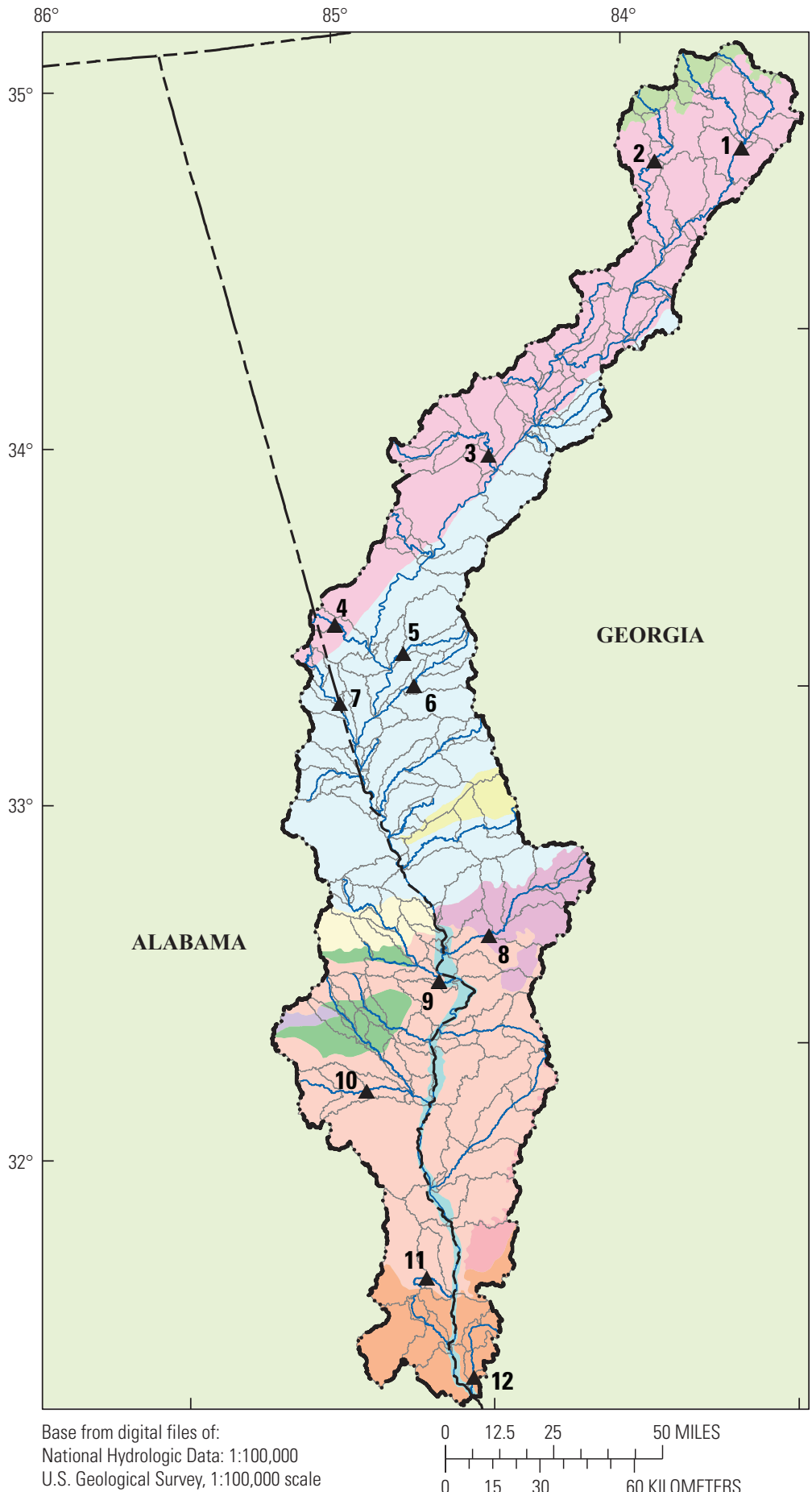

National Hydrologic Data: 1:100,000

Figure 5. Location of ecoregions, hydrologic response units, segments, and calibration stations for the Chattahoochee Precipitation-Runoff Modeling System model. 


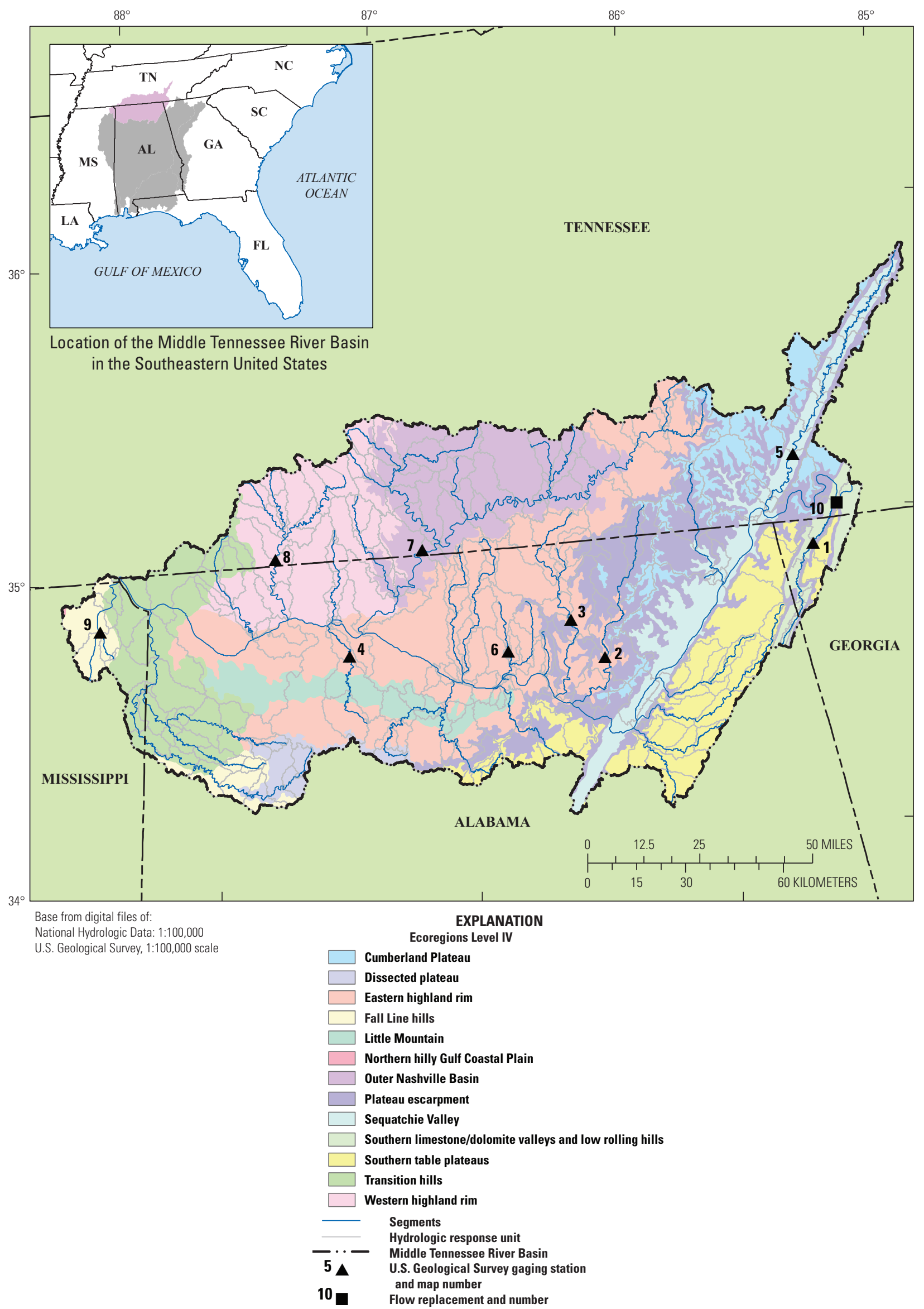

Figure 6. Location of ecoregions, hydrologic response units, segments, and calibration stations for the Middle Tennessee Precipitation-Runoff Modeling System model. 


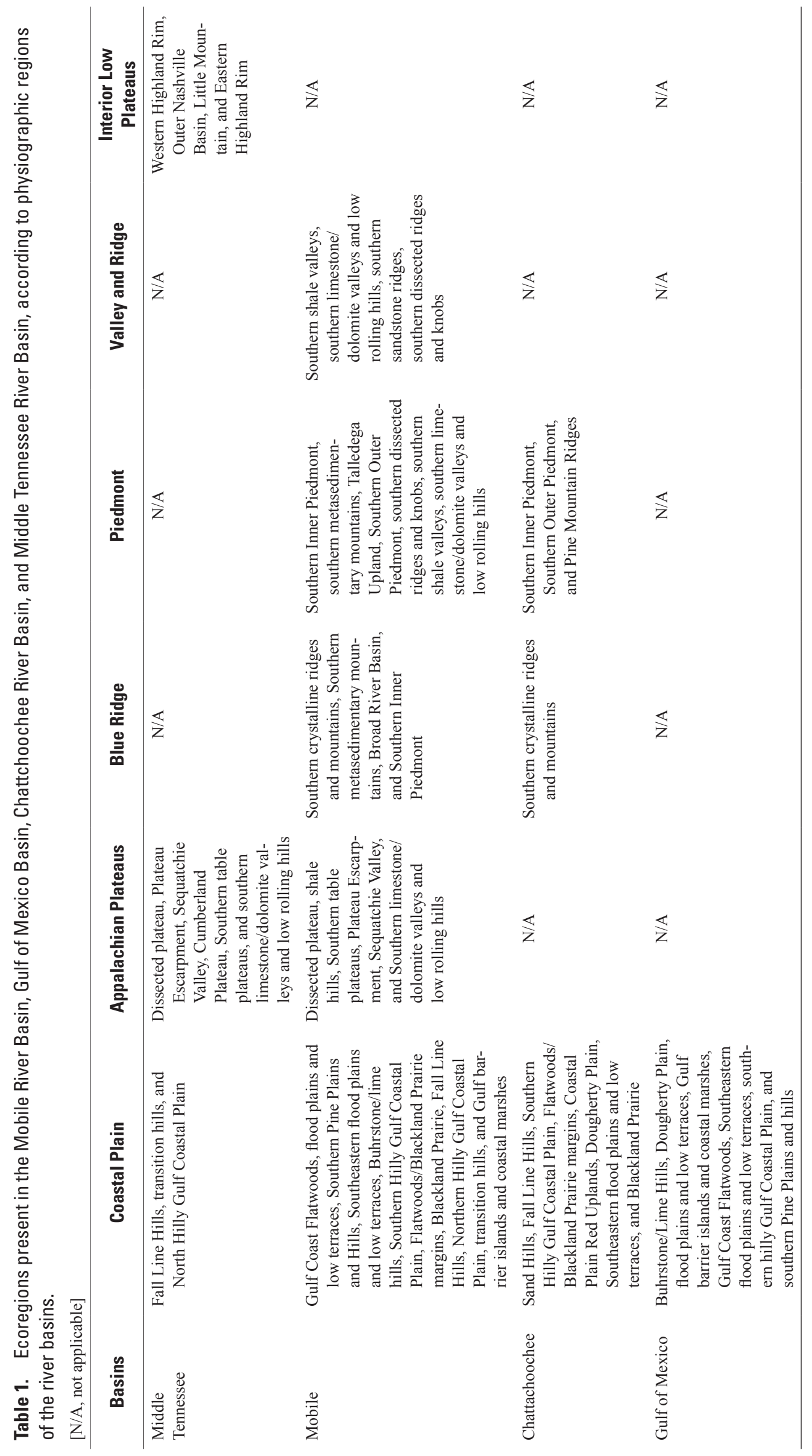




\section{Approach}

The watershed model selected for this study was the PRMS, which was developed by the USGS NRP as a tool for assessing watershed response to normal and extreme climatic conditions or to changes in the physical conditions of a watershed (Leavesley and others, 1983). The PRMS model can be used to simulate basin response to normal and extreme rainfall, to evaluate changes in water balance, flow regimes, flood peaks and volumes, soil-water relationships, and groundwater recharge. Through parameter-optimization and sensitivity analysis, the PRMS model can be calibrated to multiple streamflow gaging stations to reflect a variety of physiographic characteristics.

For this study, the PRMS was configured to estimate water availability under natural conditions. In this report, we refer to streamflow under natural conditions as streamflow derived from hydrologic processes that are not affected by anthropogenic influences, specifically diversions, dams, and water use. To accomplish this goal, the model calibration process involved review and selection of all streamflow gaging stations located in the modeled watersheds with at least 10 years of daily-flow record that reflect natural streamflow conditions with some exceptions; there were nine calibration stations that did not use at least 10 years of daily-flow records.

\section{Data}

Several types of time-series data were required for the PRMS models for calibration. Specifically, the models required long-term records (10 years or more) of daily streamflow data and climate data. The following sections provide details of these datasets.

\section{Streamflow}

Streamflow gaging stations in the modeled watershed were reviewed and those with at least 10 years of continuous recorded data for unregulated watersheds were selected to use for model calibration. The ten stations that were not calibrated for 10 years did not have long-term records or the data were considered provisional data; however, these stations were used to provide calibration data in locations where calibration stations were sparse. Most of the selected continuous streamflow records span from October 1, 1998, to September 30, 2008.

For the Mobile River Basin, 50 gaging stations were utilized during calibration (fig. 3; table 2). Approximately $13,050 \mathrm{mi}^{2}$ were calibrated compared to the $43,317 \mathrm{mi}^{2}$ that make up the Mobile River Basin. Therefore, nearly 30 percent of the Mobile River Basin was calibrated. Within the Gulf of Mexico Basin, 19 gaging stations were used for calibration (fig. 4; table 3). Approximately 4,745 $\mathrm{mi}^{2}$ were calibrated, compared to the $13,383 \mathrm{mi}^{2}$ that make up the Gulf of Mexico Basin. Therefore, approximately 35 percent of the Gulf of Mexico Basin was calibrated. The Chattahoochee River Basin used 12 gaging stations for calibration (fig. 5; table 4). Roughly $1,995 \mathrm{mi}^{2}$ were calibrated, compared to the 8,345 $\mathrm{mi}^{2}$ that make up the Chattahoochee River Basin. Therefore, approximately 24 percent of the Chattahoochee River Basin was calibrated. The Middle Tennessee River Basin model used nine gaging stations for calibration (fig. 6; table 5). Approximately 3,639 $\mathrm{mi}^{2}$ were calibrated compared to the $9,548 \mathrm{mi}^{2}$ that make up the Middle Tennessee River Basin. Therefore, approximately 38 percent of the Middle Tennessee River Basin model was calibrated. For the Middle Tennessee River Basin model, measured streamflow was used as a boundary condition at the Tennessee River at Chattanooga, Tennessee (Tenn.) (03568000) station (site 10; fig. 6). This action allowed for calibrating only the Middle Tennessee River Basin, independently from the rest of the Tennessee River Basin, while still accounting for upstream flows.

\section{Climate}

Climate data are required as input into the PRMS model; specifically, maximum and minimum temperature, and precipitation. Temperature and precipitation time-series data were obtained from the National Aeronautics Space Administration (NASA) through the Modeling and Synthesis Thematic Data Center, a unit of the North American Carbon Program (http:// daymet.ornl.gov). The dataset, called Daymet, is an interpolation of daily meteorological observations to produce gridded estimates of daily weather parameters. The weather parameters generated include daily minimum and maximum temperature, precipitation, humidity, and solar radiation on a 1-kilometer (km) by-1-km grid (Thornton and others, 2012). Using the Daymet dataset, time series of maximum temperature, minimum temperature, and precipitation from October 1, 1980, to September 30, 2008, were prepared to use as input files for PRMS on a hydrologic response unit basin.

The models were calibrated for 4 years that received below average precipitation and 7 years that received aboveaverage precipitation (fig. 1). Based on Alabama's long-term (1901-2012) annual precipitation data, Alabama's average annual precipitation value is 54.33 in. Years 1999, 2000, 2006, and 2007 had below-average precipitation, with 2000 and 2007 having the lowest average precipitation for all four models (43.61 in. and 40.08 in., respectively). In addition, during 2004 and 2005, hurricanes were contributing factors to precipitation being above average. In 2004, Alabama received from 4 to 10 in. of precipitation from Hurricane Ivan, and in 2005, Alabama received a combined rainfall of 8 to $12 \mathrm{in.}$ from both Hurricane Dennis and Hurricane Katrina. Therefore, the climate dataset used for model calibration represents years with drier than normal conditions. 
Table 2. U.S. Geological Survey streamflow gages used for calibration in the Mobile River Basin Precipitation-Runoff Modeling System model.

[mi ${ }^{2}$, square miles]

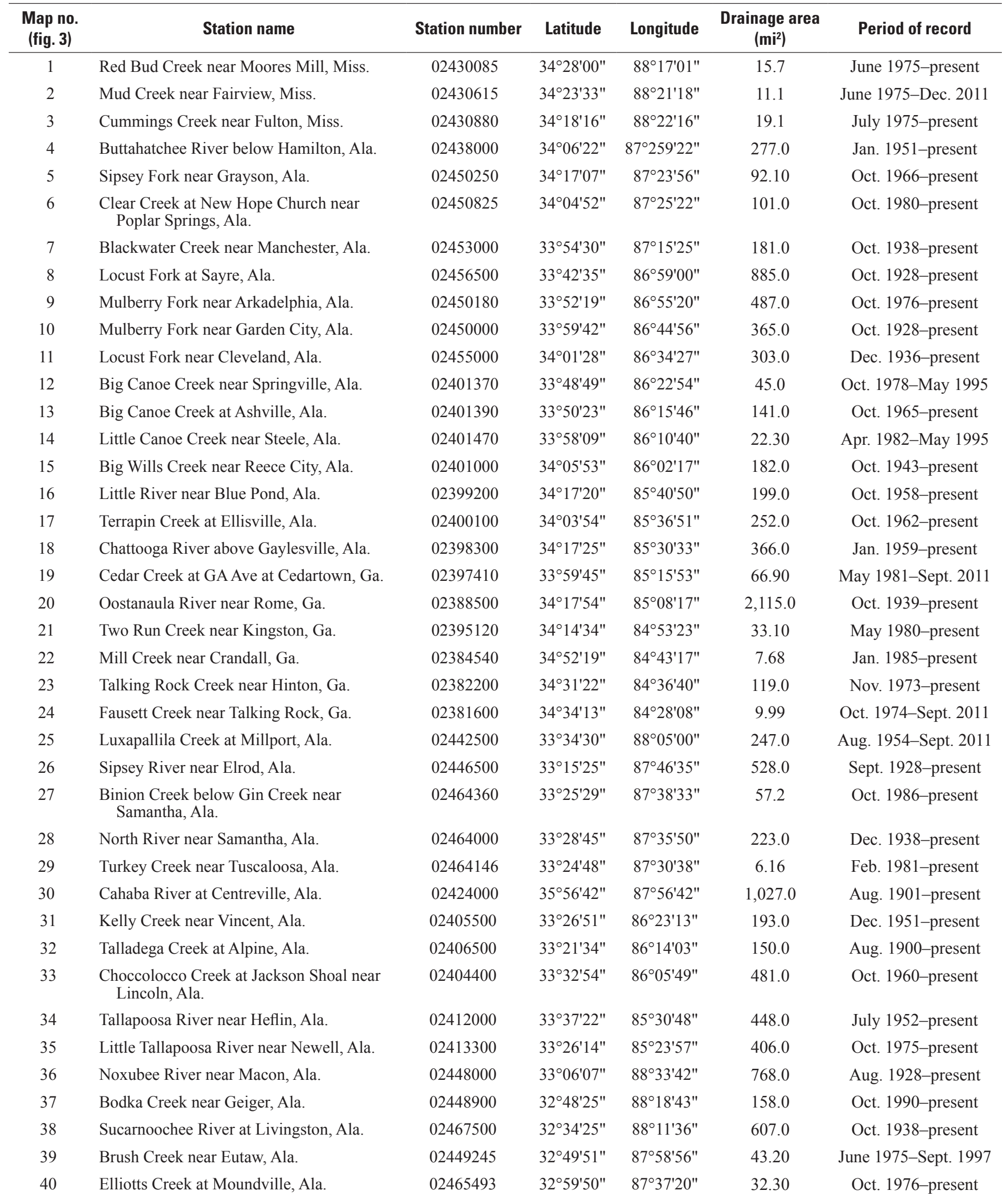


Table 2. U.S. Geological Survey streamflow gages used for calibration in the Mobile River Basin Precipitation-Runoff Modeling System model.-Continued

$\left[\mathrm{mi}^{2}\right.$, square miles $]$

\begin{tabular}{|c|c|c|c|c|c|c|}
\hline $\begin{array}{c}\text { Map no. } \\
\text { (fig. 3) }\end{array}$ & Station name & Station number & Latitude & Longitude & $\begin{array}{l}\text { Drainage area } \\
\qquad\left(\mathrm{mi}^{2}\right)\end{array}$ & Period of record \\
\hline 41 & Mulberry Creek at Jones, Ala. & 02422500 & $32^{\circ} 34^{\prime} 58^{\prime \prime}$ & $86^{\circ} 54^{\prime} 13^{\prime \prime}$ & 203.0 & Oct. 1938-present \\
\hline 43 & Hillabee Creek near Hackneyville, Ala. & 02415000 & $33^{\circ} 03^{\prime} 55^{\prime \prime}$ & $85^{\circ} 52^{\prime} 41^{\prime \prime}$ & 190.0 & July 1952-present \\
\hline 44 & Satilpa Creek near Coffeeville, Ala. & 02469800 & $31^{\circ} 44^{\prime} 39^{\prime \prime}$ & $88^{\circ} 01^{\prime} 21^{\prime \prime}$ & 164.0 & Oct. 1956-present \\
\hline 46 & Turkey Creek at Kimbrough, Ala. & 02427700 & $32^{\circ} 01^{\prime} 15^{\prime \prime}$ & $87^{\circ} 33^{\prime} 30^{\prime \prime}$ & 97.50 & Oct. 1958-Sept. 1996 \\
\hline 47 & Pine Barren Creek near Snow Hill, Ala. & 02427250 & $31^{\circ} 59^{\prime} 46^{\prime \prime}$ & $87^{\circ} 04^{\prime} 06^{\prime \prime}$ & 261.0 & Oct. 1989-present \\
\hline 48 & Catoma Creek near Montgomery, Ala. & 02421000 & $32^{\circ} 18^{\prime} 26^{\prime \prime}$ & $86^{\circ} 17^{\prime} 58^{\prime \prime}$ & 290.00 & July 1952-present \\
\hline 49 & Uphapee Creek near Tuskegee, Ala. & 02419000 & $32^{\circ} 28^{\prime} 36^{\prime \prime}$ & $85^{\circ} 41^{\prime} 42^{\prime \prime}$ & 333.0 & Oct. 1939-present \\
\hline
\end{tabular}

Table 3. U.S. Geological Survey streamflow gages used for calibration in the Gulf of Mexico Basin Precipitation-Runoff Modeling System model.

\begin{tabular}{|c|c|c|c|c|c|c|}
\hline $\begin{array}{l}\text { Map no. } \\
\text { (fig. 4) }\end{array}$ & Station name & $\begin{array}{l}\text { Station } \\
\text { number }\end{array}$ & Latitude & Longitude & $\begin{array}{l}\text { Drainage area } \\
\qquad\left(\mathrm{mi}^{2}\right)\end{array}$ & Period of record \\
\hline 1 & Pond Creek near Deer Park, Ala. & 02479431 & $31^{\circ} 09^{\prime} 39^{\prime \prime}$ & $88^{\circ} 21^{\prime} 43^{\prime \prime}$ & 20.4 & Oct. 1976-Sept. 1999 \\
\hline 2 & $\begin{array}{l}\text { Big Creek at County Road } 63 \text { near Wilmer, } \\
\text { Ala. }\end{array}$ & 02479945 & $30^{\circ} 51$ '21" & $88^{\circ} 20^{\prime} 02^{\prime \prime}$ & 31.48 & June 1990-present \\
\hline 3 & Escatawpa River near Agricola, Miss. & 02479560 & $30^{\circ} 48^{\prime} 42^{\prime \prime}$ & $88^{\circ} 27^{\prime} 31^{\prime \prime}$ & 562.00 & Aug. 1974-present \\
\hline 4 & Crooked Creek near Fairview, Ala. & 02479980 & $30^{\circ} 46^{\prime} 48^{\prime \prime}$ & $88^{\circ} 19^{\prime} 08^{\prime \prime}$ & 8.08 & June 1990-present \\
\hline 5 & Fish River near Silver Hill, Ala. & 02378500 & $30^{\circ} 32^{\prime} 43^{\prime \prime}$ & $87^{\circ} 47^{\prime} 55^{\prime \prime}$ & 55.30 & Dec. 1953-present \\
\hline 6 & $\begin{array}{l}\text { Burnt Corn Creek at State Highway } 41 \text { near } \\
\text { Brewton, Ala. }\end{array}$ & 02374745 & $31^{\circ} 07^{\prime} 47^{\prime \prime}$ & $87^{\circ} 05^{\prime} 14^{\prime \prime}$ & 182.00 & Mar. 1999-present \\
\hline 7 & Murder Creek near Evergreen, Ala. & 02374500 & $31^{\circ} 25^{\prime} 06^{\prime \prime}$ & $86^{\circ} 59^{\prime} 12^{\prime \prime}$ & 176.00 & Mar. 1938-present \\
\hline 8 & Sepulga River near Mckenzie, Ala. & 02373000 & $31^{\circ} 27^{\prime} 13^{\prime \prime}$ & $86^{\circ} 47^{\prime} 13^{\prime \prime}$ & 470.00 & Mar. 1937-present \\
\hline 9 & Patsaliga Creek near Brantley, Ala. & 02372250 & $31^{\circ} 35^{\prime} 46^{\prime \prime}$ & $86^{\circ} 24^{\prime} 20^{\prime \prime}$ & 442.00 & Nov. 1963-present \\
\hline 10 & Conecuh River at Brantley, Ala. & 02371500 & $31^{\circ} 34^{\prime} 24^{\prime \prime}$ & $86^{\circ} 15^{\prime} 06^{\prime \prime}$ & 500.00 & Mar. 1938-present \\
\hline 11 & Pea River near Ariton, Ala. & 02363000 & $31^{\circ} 35^{\prime} 41^{\prime \prime}$ & $85^{\circ} 46^{\prime} 59^{\prime \prime}$ & 498.00 & Mar. 1939-present \\
\hline 12 & Panther Creek near Hacoda, Ala. & 02364570 & $31^{\circ} 07^{\prime} 15^{\prime \prime}$ & $86^{\circ} 11^{\prime} 13^{\prime \prime}$ & 26.20 & Oct. 1974-Sept. 1995 \\
\hline 13 & $\begin{array}{l}\text { Little Double Bridges Creek near } \\
\text { Enterprise, Ala. }\end{array}$ & 02362240 & $31^{\circ} 16^{\prime} 20^{\prime \prime}$ & $85^{\circ} 57^{\prime} 30^{\prime \prime}$ & 21.40 & July $1985-$ present \\
\hline 14 & Choctawatchee River near Bellwood, Ala. & 02361500 & $31^{\circ} 09^{\prime} 33^{\prime \prime}$ & $85^{\circ} 47^{\prime} 04^{\prime \prime}$ & $1,280.00$ & Dec. 1921 - present \\
\hline 15 & Blackwater River near Baker, Fla. & 02370000 & $30^{\circ} 50^{\prime} 00^{\prime \prime}$ & $86^{\circ} 44^{\prime} 05^{\prime \prime}$ & 205.00 & Apr. $1950-$ present \\
\hline 16 & Yellow River at Milligan, Fla. & 02368000 & $30^{\circ} 45^{\prime} 10^{\prime \prime}$ & $86^{\circ} 37^{\prime} 45^{\prime \prime}$ & 624.00 & Mar. 1938- present \\
\hline 17 & $\begin{array}{l}\text { Juniper Creek at State Highway } 85 \text { near } \\
\text { Niceville, Fla. }\end{array}$ & 02367310 & $30^{\circ} 33^{\prime} 26^{\prime \prime}$ & $86^{\circ} 31^{\prime} 10^{\prime \prime}$ & 27.60 & Mar. 1966-Nov. 1993 \\
\hline 18 & Alaqua Creek near Pleasant Ridge, Fla. & 02366996 & $30^{\circ} 40^{\prime} 08^{\prime \prime}$ & $86^{\circ} 11^{\prime} 12^{\prime \prime}$ & 39.1 & Oct. 1998-Dec. 2011 \\
\hline 19 & $\begin{array}{l}\text { Bruce Creek at State Highway } 81 \text { near } \\
\text { Redbay, Fla. }\end{array}$ & 02365769 & $30^{\circ} 37^{\prime} 28^{\prime \prime}$ & $85^{\circ} 56^{\prime} 33^{\prime \prime}$ & 82.4 & Oct. 1998-Apr. 2012 \\
\hline
\end{tabular}


Table 4. U.S. Geological Survey streamflow gages used for calibration in the Chattahoochee River Basin Precipitation-Runoff Modeling System model.

\begin{tabular}{|c|c|c|c|c|c|c|}
\hline $\begin{array}{l}\text { Map no. } \\
\text { (fig. 5) }\end{array}$ & Station name & Station number & Latitude & Longitude & $\begin{array}{l}\text { Drainage area } \\
\qquad\left(\mathrm{mi}^{2}\right)\end{array}$ & Period of record \\
\hline 1 & $\begin{array}{l}\text { Chattahoochee River near } \\
\text { Cornelia, Ga. }\end{array}$ & 02331600 & $34^{\circ} 32^{\prime} 26.6^{\prime \prime}$ & $83^{\circ} 37^{\prime} 21.99^{\prime \prime}$ & 315.0 & July 1957-present \\
\hline 2 & $\begin{array}{l}\text { Chestatee River near } \\
\text { Dahlonega, Ga. }\end{array}$ & 02333500 & $34^{\circ} 31^{\prime} 41^{\prime \prime}$ & $83^{\circ} 56^{\prime} 23^{\prime \prime}$ & 153.0 & July 1929-present \\
\hline 3 & $\begin{array}{l}\text { Sweetwater Creek near } \\
\text { Austell, Ga. }\end{array}$ & 02337000 & $33^{\circ} 46^{\prime} 35.4^{\prime \prime}$ & $84^{\circ} 36^{\prime} 56.2^{\prime \prime}$ & 246.0 & May 1904-present \\
\hline 4 & $\begin{array}{l}\text { Hillabahatchee Creek at } \\
\text { Thaxton Road, near } \\
\text { Franklin, Ga. }\end{array}$ & 02338523 & $33^{\circ} 20^{\prime} 26^{\prime \prime}$ & $85^{\circ} 13^{\prime} 37^{\prime \prime}$ & 16.8 & Dec. 2001-present \\
\hline 5 & $\begin{array}{l}\text { New River at GA } 100 \text { near } \\
\text { Corinth, Ga. }\end{array}$ & 02338660 & $33^{\circ} 14^{\prime} 07^{\prime \prime}$ & $84^{\circ} 59^{\prime} 16^{\prime \prime}$ & 127.0 & Oct. 1978-present \\
\hline 6 & $\begin{array}{l}\text { Yellowjacket Creek- } \\
\text { Hammett Road below } \\
\text { Hogansville,Ga. }\end{array}$ & 02338840 & $33^{\circ} 08^{\prime} 22^{\prime \prime}$ & $84^{\circ} 58^{\prime} 31^{\prime \prime}$ & 91.0 & Oct. 1978-present \\
\hline 7 & $\begin{array}{l}\text { Wehadkee Creek below } \\
\text { Rock Mills, Ala. }\end{array}$ & 02339225 & $33^{\circ} 07^{\prime} 20^{\prime \prime}$ & $85^{\circ} 14^{\prime} 57^{\prime \prime}$ & 60.20 & Oct. 1978-Jan. 1990 \\
\hline 8 & $\begin{array}{l}\text { Upatoi Creek near } \\
\text { Columbus,Ga. }\end{array}$ & 02341800 & $32^{\circ} 24^{\prime} 48^{\prime \prime}$ & $84^{\circ} 49^{\prime} 12^{\prime \prime}$ & 342.0 & Apr. 1968-present \\
\hline 9 & $\begin{array}{l}\text { Uchee Creek near Fort } \\
\text { Mitchell, Ala. }\end{array}$ & 02342500 & $32^{\circ} 19^{\prime} 00^{\prime \prime}$ & $85^{\circ} 00^{\prime} 54^{\prime \prime}$ & 322.0 & Oct. 1946-present \\
\hline 10 & $\begin{array}{l}\text { South Fork Cowikee Creek } \\
\text { near Batesville, Ala. }\end{array}$ & 02342933 & $32^{\circ} 01^{\prime} 03^{\prime \prime}$ & $85^{\circ} 17^{\prime} 45^{\prime \prime}$ & 112.0 & Oct. 1963-Sept. 2011 \\
\hline 11 & $\begin{array}{l}\text { Abbie Creek near Haleburg, } \\
\text { Ala. }\end{array}$ & 02343300 & $31^{\circ} 28^{\prime} 24^{\prime \prime}$ & $85^{\circ} 09^{\prime} 45^{\prime \prime}$ & 146.0 & Oct. 1953-Aug. 1993 \\
\hline 12 & $\begin{array}{l}\text { Sawhatchee Creek at Cedar } \\
\text { Springs, Ga. }\end{array}$ & 02343940 & $31^{\circ} 10^{\prime} 51^{\prime \prime}$ & $85^{\circ} 02^{\prime} 37^{\prime \prime}$ & 64.2 & Jan. 2002-present \\
\hline
\end{tabular}

Table 5. U.S. Geological Survey streamflow gages used for calibration in the Middle Tennessee River Basin Precipitation-Runoff Modeling System model.

\begin{tabular}{|c|c|c|c|c|c|c|}
\hline $\begin{array}{l}\text { Map no. } \\
\text { (fig. 6) }\end{array}$ & Station name & Station number & Latitude & Longitude & $\begin{array}{c}\text { Drainage area } \\
\qquad\left(\mathrm{mi}^{2}\right)\end{array}$ & Period of record \\
\hline 1 & $\begin{array}{l}\text { Lookout Creek near New } \\
\text { England, Ga. }\end{array}$ & 03568933 & $34^{\circ} 53^{\prime} 51^{\prime \prime}$ & $85^{\circ} 27^{\prime} 47^{\prime \prime}$ & 149.00 & Aug. 1979-present \\
\hline 2 & $\begin{array}{l}\text { Paint Rock River near } \\
\text { Woodville, Ala. }\end{array}$ & 03574500 & $34^{\circ} 37^{\prime} 27^{\prime \prime}$ & $86^{\circ} 18^{\prime} 23^{\prime \prime}$ & 320.00 & Jan. 1936-present \\
\hline 3 & $\begin{array}{l}\text { Flint River at Brownsboro, } \\
\text { Ala. }\end{array}$ & 03575100 & $34^{\circ} 44^{\prime} 57^{\prime \prime}$ & $86^{\circ} 26^{\prime} 48^{\prime \prime}$ & 375.00 & Oct. 1998-present \\
\hline 4 & $\begin{array}{l}\text { Big Nance Creek at } \\
\text { Courtland, Ala. }\end{array}$ & 03586500 & $34^{\circ} 40^{\prime} 12^{\prime \prime}$ & $87^{\circ} 19^{\prime} 02^{\prime \prime}$ & 166.00 & Sept. 1935-present \\
\hline 5 & $\begin{array}{l}\text { Sequatchie River near } \\
\text { Whitwell, Tenn. }\end{array}$ & 03571000 & $35^{\circ} 12^{\prime} 23.42^{\prime \prime}$ & $85^{\circ} 29^{\prime} 49.68^{\prime \prime}$ & 402.00 & Oct. 1920-Sept. 2011 \\
\hline 6 & $\begin{array}{l}\text { Indian Creek near Madison, } \\
\text { Ala. }\end{array}$ & 03575830 & $34^{\circ} 41^{\prime} 50^{\prime \prime}$ & $86^{\circ} 42^{\prime} 00^{\prime \prime}$ & 49.00 & Oct. 1959-Dec. 2011 \\
\hline 7 & Elk River at Prospect, Tenn. & 03584600 & $35^{\circ} 00^{\prime} 50.95^{\prime \prime}$ & $86^{\circ} 59^{\prime} 40.74^{\prime \prime}$ & $1,805.00$ & July 1904-present \\
\hline 8 & $\begin{array}{l}\text { Shoal Creek at Iron City, } \\
\text { Tenn. }\end{array}$ & 03588500 & $35^{\circ} 01^{\prime} 26.54^{\prime \prime}$ & $87^{\circ} 34^{\prime} 44.43^{\prime \prime}$ & 348.00 & July 1925-present \\
\hline 9 & $\begin{array}{c}\text { Little Yellow Creek East } \\
\text { near Burnsville, Miss. }\end{array}$ & 03592718 & $34^{\circ} 50^{\prime} 08^{\prime \prime}$ & $88^{\circ} 17^{\prime} 17^{\prime \prime}$ & 24.7 & May 1973-present \\
\hline
\end{tabular}




\section{Description of the Precipitation-Runoff Modeling System Model}

PRMS is a deterministic and distributed-parameter mathematical modeling system developed to evaluate the impacts of various combinations of climate and land use on streamflow and general watershed hydrology (Leavesly and others, 1996). Basin response to normal and extreme rainfall can be simulated to evaluate changes in water balance, flow regimes, flood peaks and volumes, soil-water relationships, and groundwater recharge. Parameter-optimization and sensitivity analysis capabilities fit selected model parameters and evaluate their individual and combined effects on model output.

The PRMS components are designed around the concept of partitioning subbasins associated with a unique stream, also termed segment. Each subbasin is considered homogenous with respect to its hydrologic response and is called a hydrologic response unit (HRU). A water balance and an energy balance are computed daily for each HRU. The sum of the responses of all HRUs, weighted on a unit-area basis, produces the daily system response and streamflow from the watershed. Partioning provides the ability to impose land use or climate changes on parts of the entire watershed, and to evaluate resulting hydrologic impacts on each HRU and on the total watershed. Figure 7 shows a schematic of the PRMS model processes.

Calibration can be performed manually or with the use of a parameter optimization routine. The implementation of parameter-optimization occurs through the incorporation of an autocalibration procedure that uses the Shuffled Complex Evolution (SCE) global search algorithm (Duan and others, 1994). This feature allows the PRMS calibration to be optimized for a large number of stations and long periods of records, which was necessary for the Alabama statewide hydrologic model documented in this report.

The PRMS performance was evaluated using calibration criteria developed for the Hydrological Simulation Program Expert System (HSPEXP) (Lumb and others, 1994). In addition, the Nash-Sutcliffe model efficiency index (NSE) (Nash and Sutcliffe, 1970) and the regression correlation coefficient
$\left(\mathrm{R}^{2}\right)$ were computed. The recommended criteria values indicate the acceptable errors between the simulated and measured data. HSPEXP calculated errors measured streamflow $\left(V_{\text {meas }}\right)$ and the simulated streamflow $\left(V_{\text {sim }}\right)$ as calculated in the equation below (1). For the purpose and scope of this study, calibration criteria were based on computing errors for total volume, low flows, high flows, and summer volume.

The target calibration criteria required that the errors between simulated and measured be below the following: (1) \pm 10 percent for total-streamflow volume, (2) \pm 10 percent for low-flow volume, (3) \pm 15 percent for high-flow volume, (4) \pm 30 percent for summer volume, and (5) 0.5 for the $\mathrm{R}^{2}$.

$$
\text { Error }=\frac{\text { Vmeas }-V \operatorname{sim}}{\text { Vmeas }} \times 100 \%
$$

The NSE statistic assesses the goodness of fit of hydrologic models and ranges from $-\infty$ to 1 . An efficiency of 1 corresponds to a perfect match of simulated-to-observed data. An efficiency of zero indicates that the model predictions are as accurate as the mean of the observed data, and an efficiency less than zero occurs when the observed mean is a better predictor than the model. The NSE calculation describes the accuracy of simulated streamflow compared to measured streamflow in the equation below (2):

$$
N S E=1-\frac{\sum_{t=1}^{T}\left(Q_{m}^{t}-Q_{s}^{t}\right)^{2}}{\sum_{t=1}^{T}\left(Q_{m}^{t}-\bar{Q}_{m}\right)^{2}},
$$

where $Q_{m}^{t}$ represents the measured quantity at time, $t, Q_{m}^{t}$ represents the simulated quantity at time, $t$, and $\bar{Q}_{0}$ represents the average of the measured quantity. The $\mathrm{R}^{2}$ value, the coefficient of determination, measures how well the simulated and measured regression lines approach an ideal match and range from zero to 1 , with a value of zero indicating no correlation and a value of 1 indicating that the simulated values equal the corresponding measured values. 


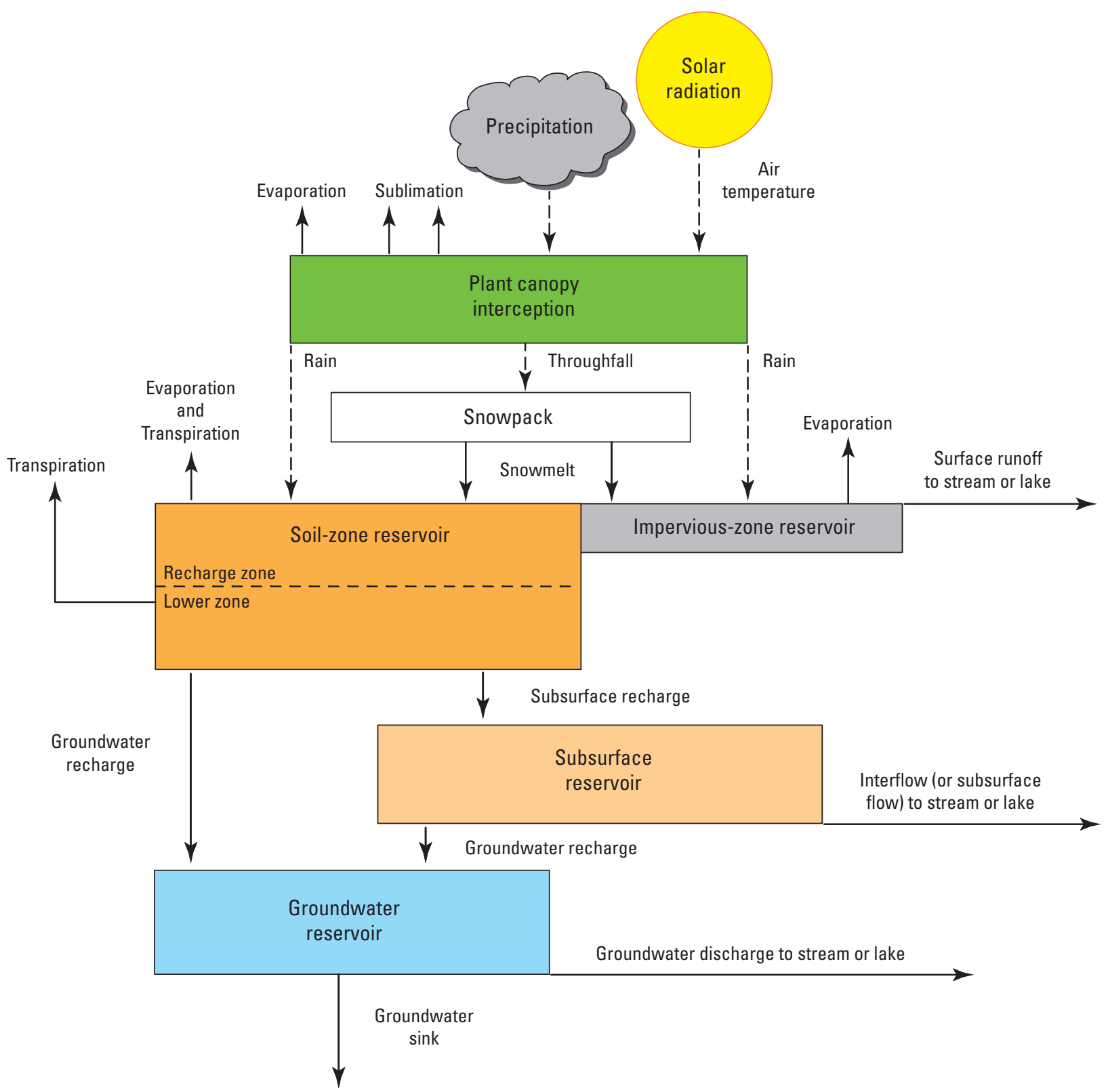

Figure 7. Schematic diagram of a watershed and its climate inputs (precipitation, air temperature, and solar radiation) simulated by the Precipitation-Runoff Modeling System (Markstrom and others, 2008). 


\section{Watershed Models for Major River Basins in Alabama}

The configuration of the watershed models for the four major river basins in Alabama are described in this section. Calibration procedures and results for all four models are described, including application of the calibrated models for assessing water availability.

\section{Model Configuration}

Individual PRMS models were developed for each of the four major river basins in figure 2, leading to four independent PRMS models: Mobile River Basin model (fig. 3), Gulf of Mexico Basin model (fig. 4), Chattahoochee River Basin model (fig. 5), and Middle Tennessee River Basin model (fig. 6). Each model was composed of HRUs and segments (table 6).

The geospatial framework needed to develop the four individual PRMS models was developed by the PRMS development team (Roger Viger, unpub. data, 2012). The framework builds on the 1:100,000-scale National Hydrography Dataset (NHD), which uses NHD-Plus version 1 as the basic hydrography. Watershed delineations were performed using NHD and 30-meter digital elevation models derived from the National Elevation Dataset (NED) to divide each model area into HRUs. Overlays of the land cover data and soil characteristics were used to initialize relevant input parameter values. Model parameters were configured to represent the best available information on existing land-management practices for each HRU. Land use data for all watersheds were derived from the 2001 National Land Cover Database (NLCD) (Homer and others, 2004), and soil layers were obtained from the State Soil Geographic (STATSGO) database (Soil Survey Staff, 2013).

The locations of the streamflow gaging stations with undisturbed drainage areas that could be considered relatively natural conditions controlled how the models were configured. Calibrated model parameters from a gaged undisturbed streamflow subbasin were applied to ungaged subbasins in the same ecoregions. For example, the Shale Hill ecoregion in Alabama generally has silt loam surfaces and a silty clay or clayey subsoil. The streams that flow through this ecoregion typically do not have a substantial base-flow component because the shale is considered impermeable (Griffith, Omernik, and Clough, 2008). The USGS gaging station Locust Fork at Sayre, Alabama (Ala.) (02456500) was located within the Shale Hill ecoregion and the calibrated parameters for this gaging station were applied to the HRUs located in the same ecoregion. This approach was utilized because the characteristics of each ecoregion are largely responsible for the hydrology of particular subbasins. This approach is illustrated for the Mobile River Basin in figure 8, where the same color of HRU grouping was associated with the calibrated parameters of the calibrated site contained therein.

Table 6. Model components of the Mobile River Basin model, Gulf of Mexico Basin model, Chattahoochcee River Basin model, and the Middle Tennessee River Basin model.

$\left[\mathrm{mi}^{2}\right.$, square miles; HRUs, hydrologic response units]

\begin{tabular}{lcrcc}
\hline & $\begin{array}{c}\text { Drainage } \\
\text { area }\left(\mathbf{m i}^{2}\right)\end{array}$ & HRUs & Segments & $\begin{array}{c}\text { Number of calibration } \\
\text { stations }\end{array}$ \\
\hline Mobile River Basin & 43,317 & 1,718 & 808 & 50 \\
Gulf of Mexico Basin & 13,383 & 439 & 203 & 19 \\
Chattahoochee River Basin & 8,345 & 383 & 186 & 12 \\
Middle Tennessee River Basin & 9,548 & 515 & 252 & 9 \\
\hline
\end{tabular}




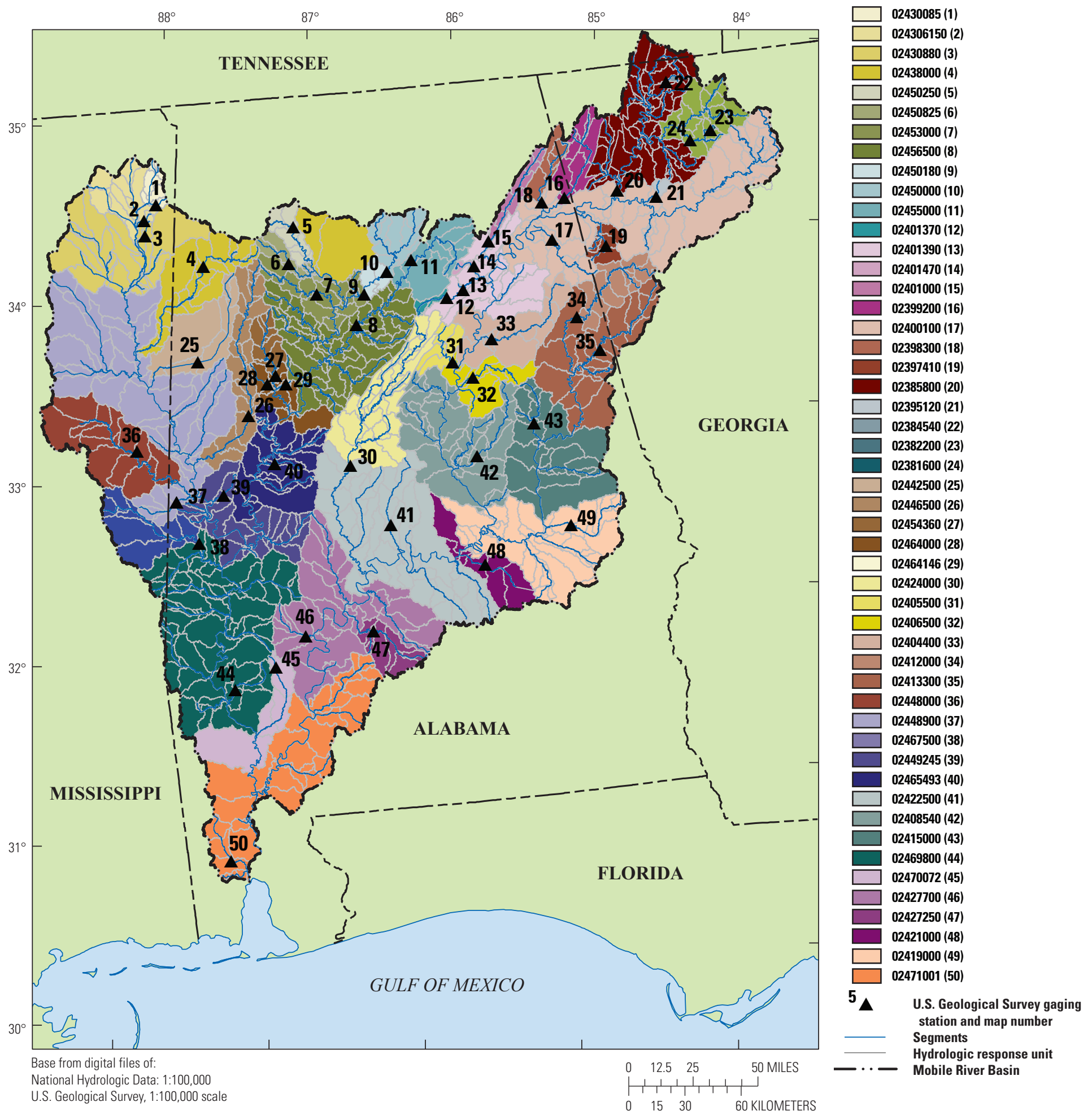

Figure 8. Illustration of the Mobile River Basin model regional calibration scheme. 


\section{Model Calibration}

The first step in the model calibration was to determine which streamflow gaging station represent undisturbed drainage areas that could be considered relatively natural conditions. Next, model parameters were optimized for the calibration stations by comparing and minimizing the difference between simulated streamflow time series to measured streamflow time series.

Two parameter optimization strategies were employed: (1) automated calibration and (2) manual calibration. The automated-calibration process involved using the Let Us Calibrate (LUCA) scheme (Hay and Umemoto, 2007). LUCA uses a five-step objective strategy to minimize model error. The objective calibration strategy within LUCA was systematic (table 7). The error in monthly water balance was minimized first by adjusting the precipitation factor (rain_adjust) on a monthly basis. The second step involved minimizing the difference of error in the daily flow timing between measured and simulated flows by calibrating the routing parameters that were determined to be the most sensitive. The third steps focused on calibrating high flows, and the fourth step focused on calibrating low flows. Calibration of high flows involved optimizing fast-flow coefficients and low flows were calibrated by optimizing groundwater parameters. The final step optimized depression storage parameters to improve timing in daily flows.

Once the autocalibration process was completed, the resulting model was evaluated. The evaluation required comparing time series of simulated streamflow and measured streamflow and calculating the errors between those data. The target calibration criteria required the errors be within the range of: (1) \pm 10 percent for total-streamflow volume, (2) \pm 10 percent for low-flow volume, (3) \pm 15 percent for high-flow volume, (4) \pm 30 percent for summer volume, and (5) above 0.5 for the $\mathrm{R}^{2}$ (table 8 ). If each of the flow characteristics for a calibration station were within the recommended criteria range, then the calibration station met the target calibration criteria and was considered well calibrated. However, if any of the errors exceeded the recommended criteria, then the manual calibration was performed. Manual calibration involved manipulating parameters, specifically slowcoef_sq, fastcoef_sq, smidx_exp, and ssr2gw_exp (see table 7), because these parameters were held constant during the automatedcalibration process. The information on the sensitivity of each parameter aided manual calibration.

A sensitivity test was performed on the parameters used for manual calibration. The sensitivity analysis was performed for the Chattahoochee River near Cornelia, Ga. (02331600) from October 1, 1998, to September 30, 2008. The sensitivity analysis algorithm evaluates changing values of each model parameter on the model output one at a time. The analysis resulted in a ranking based on sensitivity indexes. Based on this ranking, the most sensitive parameters were identified (table 9). Smidx_exp (tables 7 and 9) was the most sensitive flow parameter, whereas, ssr2gw_exp (tables 7 and 9) was the least sensitive flow parameter. 
Table 7. Precipitation-Runoff Modeling System (PRMS) automated-calibration strategy.

[HRU, hydrologic response unit; GWR, groundwater reservoir]

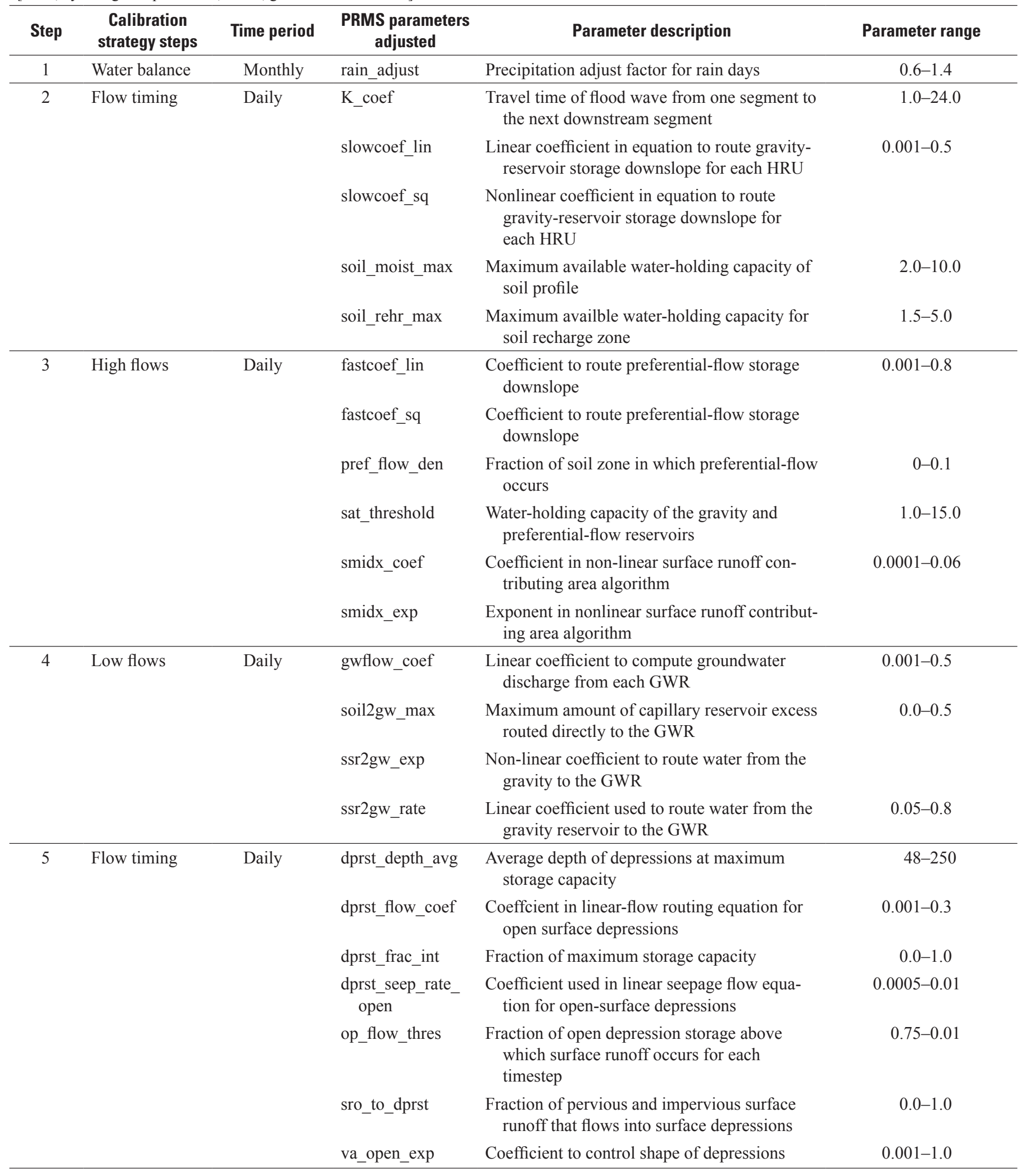


Table 8. Model calibration criteria.

$\left[\mathrm{R}^{2}\right.$, regression correlation coefficient $]$

\begin{tabular}{lc}
\hline \multicolumn{1}{c}{ Errors (simulated - observed) } & $\begin{array}{c}\text { Recommended error } \\
\text { criteria }\end{array}$ \\
\hline Error in total-streamflow volume & $\pm 10 \%$ \\
Error in low-flow volume & $\pm 10 \%$ \\
Error in high-flow volume & $\pm 15 \%$ \\
Error in summer volume & $\pm 30 \%$ \\
$\mathrm{R}^{2}$ & 0.5 \\
\hline
\end{tabular}

Table 9. Precipitation-Runoff Modeling System (PRMS) model parameter sensitivity rank for flow.

[GWR, groundwater reservoir]

\begin{tabular}{|c|c|c|c|c|}
\hline Parameter description (PRMS variable) & $\begin{array}{l}\text { Flow sensitivity } \\
\text { rank }\end{array}$ & Default value & $\begin{array}{l}\text { Above calibrated } \\
\text { value }\end{array}$ & $\begin{array}{l}\text { Below calibrated } \\
\text { value }\end{array}$ \\
\hline $\begin{array}{l}\text { Exponent in non-linear surface runoff contribution area } \\
\text { algorithm(smidx_exp) }\end{array}$ & 1 & 0.3 & 0.35 & 0.25 \\
\hline $\begin{array}{l}\text { Non-linear coefficient in equation to route gravity reservoir } \\
\text { storage down slope for each HRU(slowcoef_sq) }\end{array}$ & 2 & 0.1 & 0.15 & 0.05 \\
\hline $\begin{array}{l}\text { Coefficient to route preferential-flow storage down } \\
\text { slope(fastcoef_sq) }\end{array}$ & 3 & 0.8 & 0.85 & 0.75 \\
\hline $\begin{array}{l}\text { Non-linear coefficient to route water from the gravity } \\
\text { reservoirs to the GWR(ssr2gw_exp) }\end{array}$ & 4 & 1.2 & 1.25 & 1.15 \\
\hline
\end{tabular}

\section{Calibration Results}

The model results were evaluated against calibration criteria, described in the previous section and presented in table 8 . The Mobile River basin had 35 calibration stations that met all calibration criteria, and 15 stations that had one or more calibration criteria out of the target range (table 10). Of theses 15 stations, 8 stations had one calibration criterion that did not meet the target range. Based on a sum of calibration criteria errors, Clear Creek at New Hope Church near Poplar Springs, Ala. (02450825) in the Mobile River Basin model was considered to have the lowest overall error; total-volume error was -1.19 percent, low-flow error was -1.52 percent, high-flow error was -4.66 percent, summer-volume error was 4.28 , the $\mathrm{R}^{2}$ value between simulated and measured flows was 0.95 , and the NSE value was 0.89 . Bodka Creek near Geiger, Ala. (02448900) had the largest overall error: total-volume error was 20.10 percent, low-flow error was 92.19 percent, high-flow error was -29.89 percent, seasonal-summer error was 57.80 percent, the $\mathrm{R}^{2}$ value between simulated and measured flows was 0.90 , and the NSE value was 0.78 . Detailed summaries of results for each streamflow gaging station calibrated are presented in appendix A.

All the of the calibration stations in the Gulf of Mexico Basin model met total-streamflow, high-flow, and summervolume calibration criteria. The Gulf of Mexico Basin model had 18 stations that met all the calibration criteria and 1 station with calibration errors above the target criteria (table 11). Panther Creek near Hacoda, Ala. (02364570) had the lowest overall calibration errors: total-volume error was -0.36 percent, low-flow error was 0.77 percent, high-flow error was 5.25 percent, summer-volume error was -11.20 , the $\mathrm{R}^{2}$ value between simulated and measured flows was 0.91 , and the NSE value was 0.82 . The one station that did not meet all of the target calibration criteria met total-volume, high-flow, and summervolume calibration criteria; however, it did not meet the lowflow criteria. Pond Creek near Deer Park, Ala. (02479431) had a total-volume error of -2.61 percent, low-flow error of 32.86 percent, high-flow error of 7.09 percent, summer-volume error of -4.46 percent, an $\mathrm{R}^{2}$ value between simulated and measured flows of 0.88 , and an NSE value of 0.80 .

The Chattahoochee River Basin model had nine stations that met the calibration criteria and three stations that did not meet the calibration criteria (table 12). Based on a sum of calibration criteria errors, Uchee Creek near Fort Mitchell, Ala. (02342500) in the Chattahoochee River Basin model was considered to have the lowest overall error: total-volume error was -0.76 percent, low-flow error was -2.10 percent, highflow error was 0.38 percent, summer-volume error was 8.65 , an $\mathrm{R}^{2}$ value between simulated and measured flows of 0.99 , and an NSE value of 0.84. New River at GA 100 near Corinth, Ga. (02338660) had the largest overall error: total-volume error was 8.52 percent, low-flow error was 18.83 percent, high-flow error was 0.04 percent, summer-volume error was 25.94 percent, the $\mathrm{R}^{2}$ value between simulated and measured flows was 0.96 , and the NSE value was 0.73 .

All nine stations in the Middle Tennessee River Basin model met each recommended calibration criteria (table 13). 
Based on a sum of calibration criteria errors, Big Nance Creek at Courtland, Ala. (03586500) in the Middle Tennessee Basin model could be considered to have the lowest overall calibration error: total-volume error was -0.65 percent, low-flow error was 3.19 percent, high-flow error was 1.48 percent, summer-volume error was 2.62 , the $\mathrm{R}^{2}$ value between simulated and measured flows was 0.92 , and the NSE value was 0.86. Shoal Creek at Iron City, Tenn. (03588500) had the largest overall calibration error: total-volume error was 5.08 percent, low-flow error was -2.16 percent, a high-flow error was -11.79 percent, summer-volume error was 13.52 percent, the $\mathrm{R}^{2}$ value between simulated and measured flows was 0.95 , and the NSE value was 0.87 .

Variability in the model performance can be attributed to limitations in correctly representing certain hydrologic conditions that are characterized by some of the ecoregions in Alabama. A majority of calibration stations located in the Southern Inner Piedmont, Fall Line Hill, Eastern Highland Rim, Southern Hilly Gulf Coastal Plain, Dougherty Plain, and Dissected Plateau met all the targeted calibration criteria. In contrast, calibration stations in the Blackland Prairie and the Southern Outer Piedmont ecoregions generally did not meet the calibration criteria. Of the four stations located in the Blackland Prairie, three were poorly calibrated. The Blackland Prairie and Southern Outer Piedmont ecoregions both consist of predominately clayey soils and (or) low topographic relief. The ecoregions that were characterized by stations with more successful calibration results had loamy and sandy soils and (or) strongly sloping land. We infer that the model does well in hilly regions with sandy soils because of rapid surface runoff and more direct interaction with subsurface flow.

\section{Model Application}

The models are intended to predict streamflow at ungaged basins by applying parameters from calibrated HRUs to ungaged HRUs in the same ecoregions. The USGS station Little Tallapoosa River at U.S. Route 27 (US 27), at Carrollton, Ga. (02413000) was used to illustrate the regional approach of calibrating the model. This station was not used in the original calibration; however, this station is considered to be a streamflow gaging station with undisturbed drainage areas. Therefore, the observed flow recorded at this station reflects the relatively natural conditions that we calibrated. When comparing the observed streamflow at the Little Tallapoosa River at US 27, at Carrollton, Ga., to the simulated streamflow, there was a 1.10 percent difference in total volume, 2.89 percent difference in low flows, 1.08 percent difference in high flows, and 10.39 percent difference in summer volume. Results from applying the calibrated model to simulate streamflow are presented in figure 9.

The model can also be utilized to predict natural streamflow at regulated flow locations. For example, the USGS station Tombigbee River at Demopolis Lock and Dam near Coatopa, Ala. (02467000), is considered to be a flow-regulated location (fig. 10). During low flows, there is a statistically significant difference between the measured flow and simulated flow at this station. The measured flow value at the 90th percentile is $2,080 \mathrm{ft}^{3} / \mathrm{s}$ and the simulated flow is $5,510 \mathrm{ft}^{3} / \mathrm{s}$. Therefore, there is a 62 -percent difference between the measured flow and the simulated flow, and this difference can be attributed to withdrawls that are occurring in addition to overall model uncertainty. Therefore, this model can be used to evaluate withdrawl scenarios and determine their effects on water availability in Alabama. 
Table 10. Mobile River Basin model calibration results.

$\left[\%\right.$, percent; $\mathrm{R}^{2}$, regression correlation coefficient; NSE, Nash-Sutcliffe efficiency index; N/A, not applicable]

\begin{tabular}{|c|c|c|c|c|c|c|c|c|}
\hline \multirow{3}{*}{$\begin{array}{c}\text { Calibration } \\
\text { streamflow } \\
\text { gaging station } \\
\text { number }\end{array}$} & \multirow[t]{3}{*}{$\begin{array}{l}\text { Calibration streamflow } \\
\text { gaging station name }\end{array}$} & \multirow[t]{3}{*}{$\begin{array}{l}\text { Calibration } \\
\text { period }\end{array}$} & \multirow[t]{2}{*}{$\begin{array}{l}\text { Error in total- } \\
\text { streamflow } \\
\text { volume }(\%)\end{array}$} & $\begin{array}{c}\text { Error in } \\
\text { low- } \\
\text { flow } \\
\text { volume } \\
(\%)\end{array}$ & \multirow[t]{2}{*}{$\begin{array}{c}\text { Error in } \\
\text { high- } \\
\text { flow } \\
\text { volume } \\
(\%)\end{array}$} & \multirow{2}{*}{$\begin{array}{c}\text { Error in } \\
\text { summer } \\
\text { volume } \\
(\%)\end{array}$} & \multirow[t]{2}{*}{$\mathbf{R}^{2}$} & \multirow[t]{2}{*}{ NSE } \\
\hline & & & & Calibration criteria & & & & \\
\hline & & & \pm 10 & \pm 10 & \pm 15 & \pm 30 & 0.5 & N/A \\
\hline 02430085 & $\begin{array}{l}\text { Red Bud Creek near Moores } \\
\text { Mill, Miss. }\end{array}$ & $\begin{array}{r}10 / 1 / 1997- \\
9 / 30 / 2008\end{array}$ & -6.30 & 0.84 & -13.28 & 19.97 & 0.95 & 0.81 \\
\hline 02438000 & $\begin{array}{l}\text { Buttahatchee River below } \\
\text { Hamilton, Ala. }\end{array}$ & $\begin{array}{r}10 / 1 / 1997- \\
9 / 30 / 2008\end{array}$ & 4.17 & 3.17 & 14.80 & 23.10 & 0.89 & 0.85 \\
\hline 02442500 & $\begin{array}{l}\text { Luxapallila Creek at Millport, } \\
\text { Ala. }\end{array}$ & $\begin{array}{l}11 / 1 / 2001- \\
9 / 30 / 2008 *\end{array}$ & 1.57 & 3.79 & -1.30 & 15.27 & 0.98 & 0.91 \\
\hline 02446500 & Sipsey River near Elrod, Ala. & $\begin{array}{l}10 / 1 / 1997- \\
9 / 30 / 2008\end{array}$ & 0.88 & 6.77 & -5.37 & 15.01 & 0.97 & 0.92 \\
\hline 02448000 & $\begin{array}{l}\text { Noxubee River near Macon, } \\
\text { Miss. }\end{array}$ & $\begin{array}{r}10 / 1 / 1997- \\
9 / 30 / 2008\end{array}$ & -0.67 & 9.59 & -4.72 & 9.91 & 0.97 & 0.84 \\
\hline 02450000 & $\begin{array}{l}\text { Mulberry Fork near Garden City, } \\
\text { Ala. }\end{array}$ & $\begin{array}{r}10 / 1 / 1987- \\
9 / 30 / 1997\end{array}$ & 1.43 & 6.34 & -12.25 & 25.74 & 0.91 & 0.86 \\
\hline 02450250 & Sipsey Fork near Grayson, Ala. & $\begin{array}{r}10 / 1 / 1997- \\
9 / 30 / 2008\end{array}$ & 3.97 & 6.33 & 7.95 & 19.16 & 0.98 & 0.88 \\
\hline 02455000 & Locust Fork near Cleveland, Ala. & $\begin{array}{r}10 / 1 / 1997- \\
9 / 30 / 2008\end{array}$ & -1.68 & -8.61 & -2.28 & 19.15 & 0.96 & 0.91 \\
\hline 02464000 & North River near Samantha, Ala. & $\begin{array}{r}10 / 1 / 1997- \\
9 / 30 / 2008\end{array}$ & 2.92 & -5.93 & -4.53 & 24.03 & 0.93 & 0.86 \\
\hline 02464146 & $\begin{array}{l}\text { Turkey Creek near Tuscaloosa, } \\
\text { Ala. }\end{array}$ & $\begin{array}{r}10 / 1 / 1997- \\
9 / 30 / 2008\end{array}$ & 0.57 & 3.81 & 6.04 & 12.85 & 0.92 & 0.76 \\
\hline 02467500 & $\begin{array}{l}\text { Sucarnoochee River at Livings- } \\
\text { ton, Ala. }\end{array}$ & $\begin{array}{l}10 / 1 / 1998- \\
9 / 30 / 2008\end{array}$ & 6.70 & 9.19 & -1.93 & 25.54 & 0.92 & 0.83 \\
\hline 02412000 & $\begin{array}{l}\text { Tallapoosa River near Heflin, } \\
\text { Ala. }\end{array}$ & $\begin{array}{l}10 / 1 / 1997- \\
9 / 30 / 2008\end{array}$ & 1.09 & -9.33 & -5.50 & 3.68 & 0.94 & 0.87 \\
\hline 02381600 & $\begin{array}{l}\text { Fausett Creek near Talking } \\
\text { Rock, Ga. }\end{array}$ & $\begin{array}{r}10 / 1 / 1997- \\
9 / 30 / 2008\end{array}$ & 1.13 & 9.97 & -1.04 & 10.38 & 0.81 & 0.69 \\
\hline 02384540 & Mill Creek near Crandall, Ga. & $\begin{array}{r}10 / 1 / 1997- \\
9 / 30 / 2008\end{array}$ & 7.84 & 3.26 & 9.07 & 3.09 & 0.88 & 0.75 \\
\hline 02395120 & $\begin{array}{l}\text { Two Run Creek near Kingston, } \\
\text { Ga. }\end{array}$ & $\begin{array}{r}10 / 1 / 1997- \\
9 / 30 / 2008\end{array}$ & -12.93 & 1.37 & -19.81 & 8.62 & 0.87 & 0.74 \\
\hline 02397410 & $\begin{array}{l}\text { Cedar Creek at GA Ave at } \\
\text { Cedartown, Ga. }\end{array}$ & $\begin{array}{r}10 / 1 / 1987- \\
9 / 30 / 1997\end{array}$ & -1.65 & -0.84 & -3.91 & 17.88 & 0.94 & 0.88 \\
\hline 02398300 & $\begin{array}{l}\text { Chattooga River above } \\
\text { Gaylesville, Ala. }\end{array}$ & $\begin{array}{r}10 / 1 / 1997- \\
9 / 30 / 2008\end{array}$ & 9.10 & 7.75 & -2.66 & 25.22 & 0.97 & 0.90 \\
\hline 02399200 & Little River near Blue Pond, Ala. & $\begin{array}{r}10 / 1 / 1997- \\
9 / 30 / 2008\end{array}$ & -5.20 & 9.86 & -7.52 & 14.18 & 0.97 & 0.93 \\
\hline 02401000 & $\begin{array}{l}\text { Big Wills Creek near Reece } \\
\text { City, Ala. }\end{array}$ & $\begin{array}{r}10 / 1 / 1997- \\
9 / 30 / 2008\end{array}$ & -3.65 & 7.80 & -8.79 & 3.56 & 0.98 & 0.91 \\
\hline 02401370 & $\begin{array}{l}\text { Big Canoe Creek near Spring- } \\
\text { ville, Ala. }\end{array}$ & $\begin{array}{r}10 / 1 / 1984- \\
9 / 30 / 1994\end{array}$ & -5.18 & 9.06 & -11.26 & 5.22 & 0.96 & 0.89 \\
\hline 02401470 & $\begin{array}{l}\text { Little Canoe Creek near Steele, } \\
\text { Ala. }\end{array}$ & $\begin{array}{r}10 / 1 / 1984 \\
9 / 30 / 1994\end{array}$ & -4.14 & -2.46 & -3.85 & -14.76 & 0.96 & 0.89 \\
\hline 02405500 & Kelly Creek near Vincent, Ala. & $\begin{array}{r}10 / 1 / 1997- \\
9 / 30 / 2008\end{array}$ & 0.14 & 13.71 & 0.62 & 21.38 & 0.93 & 0.89 \\
\hline 02424000 & Cahaba River at Centreville, Ala. & $\begin{array}{r}10 / 1 / 1997- \\
9 / 30 / 2008\end{array}$ & 6.10 & 5.87 & -5.63 & 17.42 & 0.96 & 0.92 \\
\hline 02427250 & $\begin{array}{l}\text { Pine Barren Creek near Snow } \\
\text { Hill, Ala. }\end{array}$ & $\begin{array}{r}10 / 1 / 1997- \\
9 / 30 / 2008\end{array}$ & 3.85 & 9.28 & 13.30 & -16.96 & 0.98 & 0.87 \\
\hline 02430615 & Mud Creek near Fairview, Miss. & $\begin{array}{l}10 / 1 / 1998- \\
9 / 30 / 2008\end{array}$ & 0.94 & 3.08 & 9.73 & 21.90 & 0.93 & 0.75 \\
\hline 02450180 & $\begin{array}{l}\text { Mulberry Fork near Arkadephia, } \\
\text { Ala. }\end{array}$ & $\begin{array}{l}10 / 1 / 1998- \\
9 / 30 / 2008\end{array}$ & 8.27 & 8.05 & -0.45 & 37.95 & 0.90 & 0.83 \\
\hline 02450825 & $\begin{array}{l}\text { Clear Creek at New Hope } \\
\text { Church near Poplar Springs, } \\
\text { Ala. }\end{array}$ & $\begin{array}{l}10 / 1 / 1997- \\
9 / 30 / 2008\end{array}$ & -1.19 & -1.52 & -4.66 & 4.28 & 0.95 & 0.89 \\
\hline
\end{tabular}


Table 10. Mobile River Basin model calibration results.-Continued

$\left[\%\right.$, percent; $\mathrm{R}^{2}$, regression correlation coefficient; NSE, Nash-Sutcliffe efficiency index; N/A, not applicable $]$

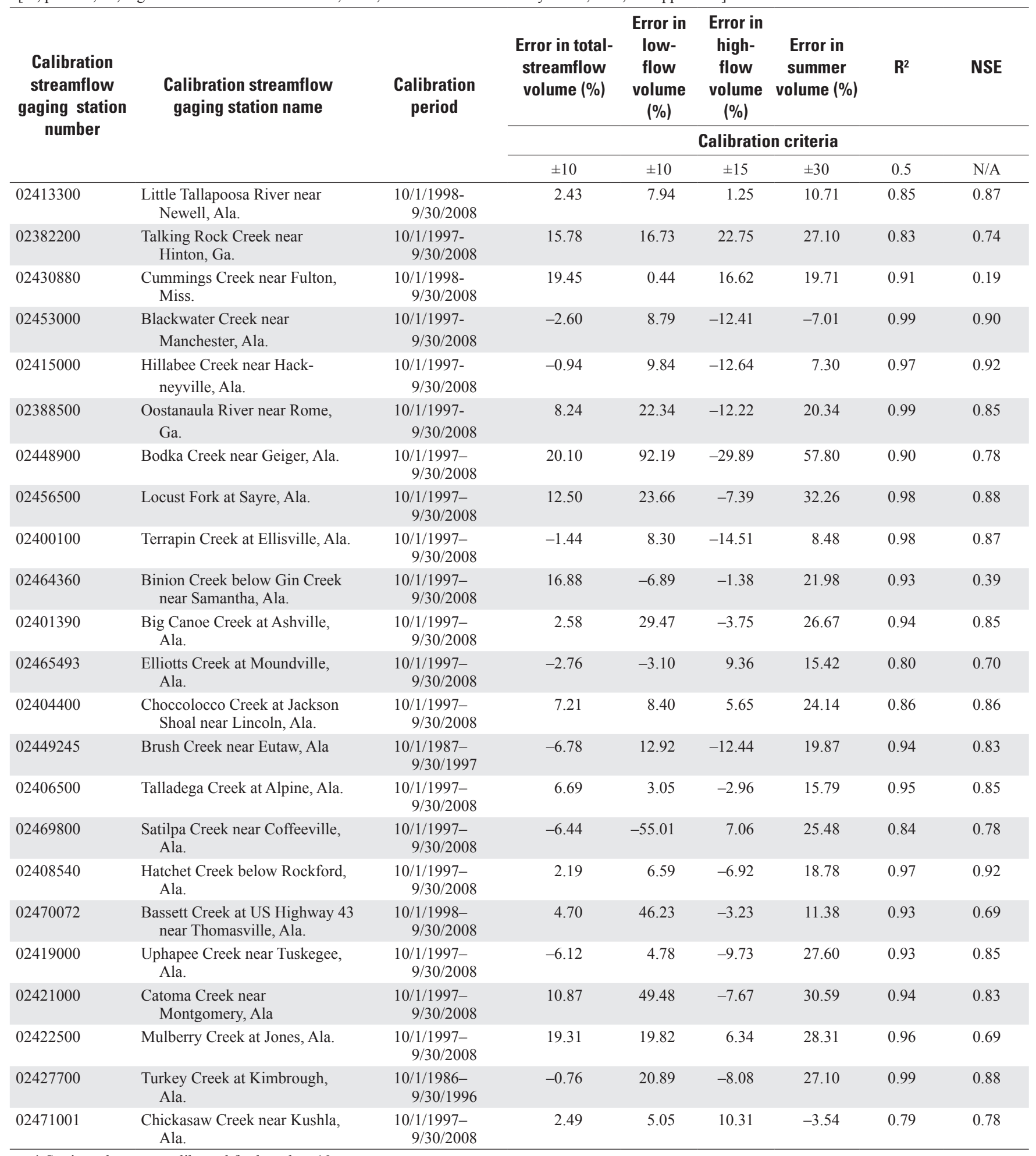

* Stations that were calibrated for less than 10 years. 
Table 11. Gulf of Mexico Basin model calibration results.

$\left[\%\right.$, percent; $\mathrm{R}^{2}$, regression correlation coefficient; NSE, Nash-Sutcliffe efficiency index; N/A, not applicable]

\begin{tabular}{|c|c|c|c|c|c|c|c|c|}
\hline \multirow[t]{3}{*}{$\begin{array}{c}\text { Calibration } \\
\text { streamflow } \\
\text { gaging station } \\
\text { number }\end{array}$} & \multirow[t]{3}{*}{$\begin{array}{l}\text { Calibration streamflow } \\
\text { gaging station name }\end{array}$} & \multirow[t]{3}{*}{$\begin{array}{l}\text { Calibration } \\
\text { period }\end{array}$} & $\begin{array}{c}\text { Error in total- } \\
\text { streamflow } \\
\text { volume }(\%)\end{array}$ & $\begin{array}{l}\text { Error in } \\
\text { low- } \\
\text { flow } \\
\text { volume } \\
(\%)\end{array}$ & $\begin{array}{l}\text { Error in } \\
\text { high- } \\
\text { flow } \\
\text { volume } \\
(\%)\end{array}$ & $\begin{array}{l}\text { Error in } \\
\text { summer } \\
\text { volume } \\
(\%)\end{array}$ & $\mathbf{R}^{2}$ & NSE \\
\hline & & & \multicolumn{6}{|c|}{ Calibration criteria } \\
\hline & & & \pm 10 & \pm 10 & \pm 15 & \pm 30 & 0.5 & N/A \\
\hline 02367310 & $\begin{array}{l}\text { Juniper Creek at State Highway } \\
85 \text { near Niceville, Fla. }\end{array}$ & $\begin{array}{l}\text { 10/1/1983- } \\
\text { 9/30/1993 }\end{array}$ & -7.01 & -3.23 & 1.76 & -8.21 & 0.62 & 0.45 \\
\hline 02366996 & $\begin{array}{l}\text { Alaqua Creek near Pleasant } \\
\text { Ridge, Fla. }\end{array}$ & $\begin{array}{l}\text { 10/1/1999- } \\
9 / 30 / 2008 *\end{array}$ & -3.59 & 2.98 & -8.11 & -9.96 & 0.67 & 0.71 \\
\hline 02368000 & Yellow River at Milligan, Fla. & $\begin{array}{l}\text { 10/1/1998- } \\
\text { 9/30/2008 }\end{array}$ & -9.42 & -1.66 & -13.81 & 7.82 & 0.89 & 0.86 \\
\hline 02361000 & $\begin{array}{l}\text { Choctawhatchee River near } \\
\text { Newton, Ala. }\end{array}$ & $\begin{array}{l}1 / 1 / 2001- \\
9 / 30 / 2008 *\end{array}$ & 4.33 & -7.94 & 12.87 & 10.13 & 0.96 & 0.71 \\
\hline 02363000 & Pea River near Ariton, Ala. & $\begin{array}{l}\text { 10/1/1998- } \\
9 / 30 / 2008\end{array}$ & 1.32 & 6.84 & 14.97 & 28.31 & 0.87 & 0.76 \\
\hline 02371500 & Conecuh River at Brantley, Ala. & $\begin{array}{l}10 / 1 / 1998- \\
9 / 30 / 2008\end{array}$ & -6.30 & 6.09 & 2.27 & 5.02 & 0.95 & 0.86 \\
\hline 02374500 & $\begin{array}{l}\text { Murder Creek near Evergreen, } \\
\text { Ala. }\end{array}$ & $\begin{array}{l}\text { 10/1/1998- } \\
\text { 9/30/2008 }\end{array}$ & -7.38 & 3.40 & -10.08 & 6.73 & 0.81 & 0.74 \\
\hline 02479431 & Pond Creek near Deer Park, Ala. & $\begin{array}{l}\text { 10/1/1989- } \\
9 / 30 / 1999\end{array}$ & -2.61 & 32.86 & 7.09 & -4.46 & 0.88 & 0.80 \\
\hline 02479980 & $\begin{array}{l}\text { Crooked Creek near Fairview, } \\
\text { Ala. }\end{array}$ & $\begin{array}{l}\text { 10/1/1998- } \\
\text { 9/30/2008 }\end{array}$ & 8.12 & 9.16 & 8.77 & 13.34 & 0.74 & 0.62 \\
\hline 02378500 & Fish River near Silver Hill, Ala. & $\begin{array}{l}\text { 10/1/1998- } \\
\text { 9/30/2008 }\end{array}$ & -0.99 & 5.80 & -11.80 & 2.18 & 0.85 & 0.86 \\
\hline 02370000 & $\begin{array}{l}\text { Blackwater River near Baker, } \\
\text { Fla. }\end{array}$ & $\begin{array}{l}\text { 10/1/1997- } \\
\text { 9/30/2008 }\end{array}$ & 1.64 & 9.94 & 3.09 & 7.39 & 0.74 & 0.83 \\
\hline 02362240 & $\begin{array}{l}\text { Little Double Bridges Creek } \\
\text { near Enterprise, Ala. }\end{array}$ & $\begin{array}{l}\text { 10/1/1997- } \\
\text { 9/30/2008 }\end{array}$ & 8.45 & -9.68 & 14.98 & 15.37 & 0.92 & 0.71 \\
\hline 02372250 & $\begin{array}{l}\text { Patsaliga Creek near Brantley, } \\
\text { Ala. }\end{array}$ & $\begin{array}{l}\text { 10/1/1997- } \\
\text { 9/30/2008 }\end{array}$ & -2.84 & -6.33 & 9.75 & 10.53 & 0.73 & 0.69 \\
\hline 02479945 & $\begin{array}{l}\text { Big Creek at County Road } 63 \\
\text { near Wilmer, Ala. }\end{array}$ & $\begin{array}{l}\text { 10/1/1997- } \\
\text { 9/30/2008 }\end{array}$ & 7.26 & 9.76 & 13.60 & 12.82 & 0.71 & 0.57 \\
\hline 02364570 & Panther Creek near Hacoda, Ala. & $\begin{array}{l}\text { 10/1/1985- } \\
9 / 30 / 1995\end{array}$ & -0.36 & 0.77 & 5.25 & -11.20 & 0.91 & 0.82 \\
\hline 02373000 & $\begin{array}{l}\text { Sepulga River near Mckenzie, } \\
\text { Ala. }\end{array}$ & $\begin{array}{l}\text { 10/1/1997- } \\
9 / 30 / 2008\end{array}$ & -4.99 & 8.35 & 4.96 & 12.75 & 0.74 & 0.71 \\
\hline 02479560 & $\begin{array}{l}\text { Escatawpa River near Agricola, } \\
\text { Miss. }\end{array}$ & $\begin{array}{l}\text { 10/1/1997- } \\
\text { 9/30/2008 }\end{array}$ & 7.36 & 8.76 & 9.09 & 9.72 & 0.93 & 0.88 \\
\hline 02365769 & $\begin{array}{l}\text { Bruce Creek at State Highway } \\
81 \text { near Redbay, Fla. }\end{array}$ & $\begin{array}{l}10 / 1 / 1998- \\
9 / 30 / 2008\end{array}$ & -0.36 & 8.07 & -6.36 & 3.31 & 0.64 & 0.74 \\
\hline 02374745 & $\begin{array}{l}\text { Burnt Corn Creek at State High- } \\
\text { way } 41 \text { near Brewton, Ala. }\end{array}$ & $\begin{array}{l}\text { 4/1/1999- } \\
\text { 9/30/2008* }\end{array}$ & 3.67 & 9.25 & 10.33 & 13.42 & 0.83 & 0.83 \\
\hline
\end{tabular}

* Stations that were calibrated for less than 10 years. 
Table 12. Chattahoochee River Basin model calibration results.

$\left[\%\right.$, percent; $\mathrm{R}^{2}$, regression correlation coefficient; NSE, Nash-Sutcliffe efficiency index; N/A, not applicable]

\begin{tabular}{|c|c|c|c|c|c|c|c|c|}
\hline \multirow[t]{3}{*}{$\begin{array}{c}\text { Calibration } \\
\text { streamflow } \\
\text { gaging station } \\
\text { number }\end{array}$} & \multirow[t]{3}{*}{$\begin{array}{l}\text { Calibration streamflow } \\
\text { gaging station name }\end{array}$} & \multirow[t]{3}{*}{$\begin{array}{l}\text { Calibration } \\
\text { period }\end{array}$} & $\begin{array}{c}\text { Error in total- } \\
\text { streamflow } \\
\text { volume (\%) }\end{array}$ & $\begin{array}{l}\text { Error in } \\
\text { low- } \\
\text { flow } \\
\text { volume } \\
(\%)\end{array}$ & $\begin{array}{l}\text { Error in } \\
\text { high- } \\
\text { flow } \\
\text { volume } \\
(\%)\end{array}$ & $\begin{array}{l}\text { Error in } \\
\text { summer } \\
\text { volume } \\
(\%)\end{array}$ & $\mathbf{R}^{2}$ & NSE \\
\hline & & & \multicolumn{6}{|c|}{ Calibration criteria } \\
\hline & & & \pm 10 & \pm 10 & \pm 15 & \pm 30 & 0.5 & N/A \\
\hline 02331600 & $\begin{array}{l}\text { Chattahoochee River near } \\
\text { Cornelia, Ga. }\end{array}$ & $\begin{array}{l}10 / 1 / 1998- \\
9 / 30 / 2008\end{array}$ & -0.01 & 8.27 & -8.84 & 9.55 & 0.90 & 0.92 \\
\hline 02333500 & $\begin{array}{l}\text { Chestatee River near Dahlonega, } \\
\text { Ga. }\end{array}$ & $\begin{array}{l}\text { 10/1/1998- } \\
9 / 30 / 2008\end{array}$ & 5.52 & 12.35 & -2.52 & 10.28 & 0.92 & 0.86 \\
\hline 02337000 & $\begin{array}{l}\text { Sweetwater Creek near Austell, } \\
\text { Ga. }\end{array}$ & $\begin{array}{l}10 / 1 / 1998- \\
9 / 30 / 2008\end{array}$ & 7.49 & 1.99 & -0.42 & 16.99 & 0.98 & 0.85 \\
\hline 02338523 & $\begin{array}{l}\text { Hillabahatchee Creek at Thaxton } \\
\text { Road near Franklin, Ga. }\end{array}$ & $\begin{array}{l}\text { 10/1/2002- } \\
\text { 9/30/2008 * }\end{array}$ & 3.14 & -1.75 & 9.08 & 8.99 & 0.71 & 0.76 \\
\hline 02338660 & $\begin{array}{l}\text { New River at GA } 100 \text { near } \\
\text { Corinth, Ga. }\end{array}$ & $\begin{array}{l}10 / 1 / 1997- \\
9 / 30 / 2008\end{array}$ & 8.52 & 18.83 & 0.04 & 25.94 & 0.96 & 0.73 \\
\hline 02338840 & $\begin{array}{l}\text { Yellowjacket Creek-Hammett } \\
\text { Road below Hogansville, Ga. }\end{array}$ & $\begin{array}{l}\text { 10/1/1980- } \\
9 / 30 / 1985\end{array}$ & 3.12 & -13.30 & -1.86 & 18.53 & 0.95 & 0.86 \\
\hline 02339225 & $\begin{array}{l}\text { Wehadkee Creek below Rock } \\
\text { Mills, Ala. }\end{array}$ & $\begin{array}{l}\text { 10/1/1980- } \\
\text { 9/30/1989 * }\end{array}$ & 2.10 & -4.81 & 5.02 & 7.89 & 0.91 & 0.82 \\
\hline 02341800 & $\begin{array}{l}\text { Upatoi Creek near Columbus, } \\
\text { Ga. }\end{array}$ & $\begin{array}{l}\text { 10/1/1997- } \\
9 / 30 / 2008\end{array}$ & 2.54 & 3.81 & 1.09 & 23.30 & 0.90 & 0.78 \\
\hline 02342500 & $\begin{array}{l}\text { Uchee Creek near Fort Mitchell, } \\
\text { Ala. }\end{array}$ & $\begin{array}{r}\text { 10/1/1997- } \\
9 / 30 / 2008\end{array}$ & -0.76 & -2.10 & 0.38 & 8.65 & 0.99 & 0.84 \\
\hline 02342933 & $\begin{array}{l}\text { South Fork Cowikee Creek near } \\
\text { Batesville, Ala. }\end{array}$ & $\begin{array}{r}10 / 1 / 1997- \\
9 / 30 / 2008\end{array}$ & 3.91 & 3.34 & 4.49 & 19.95 & 0.92 & 0.76 \\
\hline 02343300 & Abbie Creek near Haleburg, Ala. & $\begin{array}{l}\text { 10/1/1982- } \\
9 / 30 / 1992\end{array}$ & -2.28 & 1.16 & -7.16 & 19.23 & 0.97 & 0.71 \\
\hline 02343940 & $\begin{array}{l}\text { Sawhatchee Creek at Cedar } \\
\text { Springs, Ga. }\end{array}$ & $\begin{array}{l}\text { 10/1/2002- } \\
\text { 9/30/2008* }\end{array}$ & 1.04 & 0.53 & 3.37 & 11.73 & 0.97 & 0.90 \\
\hline
\end{tabular}

* Stations that were calibrated for less than 10 years.

Table 13. Middle Tennessee River Basin model calibration results.

$\left[\%\right.$, percent; $\mathrm{R}^{2}$, regression correlation coefficient; NSE, Nash-Sutcliffe efficiency index; N/A, not applicable]

\begin{tabular}{|c|c|c|c|c|c|c|c|c|}
\hline \multirow[t]{3}{*}{$\begin{array}{c}\text { Calibration } \\
\text { streamflow } \\
\text { gaging station } \\
\text { number }\end{array}$} & \multirow[t]{3}{*}{$\begin{array}{l}\text { Calibration streamflow } \\
\text { gaging station name }\end{array}$} & \multirow[t]{3}{*}{$\begin{array}{l}\text { Calibration } \\
\text { period }\end{array}$} & $\begin{array}{c}\text { Error in total- } \\
\text { streamflow } \\
\text { volume }(\%)\end{array}$ & $\begin{array}{c}\text { Error in } \\
\text { low- } \\
\text { flow } \\
\text { volume } \\
(\%)\end{array}$ & $\begin{array}{l}\text { Error in } \\
\text { high- } \\
\text { flow } \\
\text { volume } \\
(\%)\end{array}$ & $\begin{array}{c}\text { Error in } \\
\text { summer } \\
\text { volume } \\
(\%)\end{array}$ & $\mathbf{R}^{2}$ & NSE \\
\hline & & & \multicolumn{6}{|c|}{ Calibration criteria } \\
\hline & & & \pm 10 & \pm 10 & \pm 15 & \pm 30 & 0.5 & N/A \\
\hline 03568933 & $\begin{array}{l}\text { Lookout Creek near New Eng- } \\
\text { land, Ga. }\end{array}$ & $\begin{array}{r}10 / 1 / 1997- \\
9 / 30 / 2008\end{array}$ & 0.01 & 9.54 & -12.52 & -2.28 & 0.99 & 0.87 \\
\hline 03574500 & $\begin{array}{l}\text { Paint Rock River near Wood- } \\
\text { ville, Ala. }\end{array}$ & $\begin{array}{r}\text { 10/1/1997- } \\
9 / 30 / 2008\end{array}$ & 0.07 & 4.01 & -8.83 & -11.42 & 0.98 & 0.87 \\
\hline 03575100 & Flint River at Brownsboro, Ala. & $\begin{array}{l}\text { 10/1/1998- } \\
9 / 30 / 2008\end{array}$ & 2.33 & 7.48 & -7.69 & 11.26 & 0.99 & 0.88 \\
\hline 03586500 & $\begin{array}{l}\text { Big Nance Creek at Courtland, } \\
\text { Ala. }\end{array}$ & $\begin{array}{c}10 / 1 / 1997- \\
9 / 30 / 2008\end{array}$ & -0.65 & 3.19 & 1.48 & 2.62 & 0.92 & 0.86 \\
\hline 03571000 & $\begin{array}{l}\text { Sequatchie River near Whitwell, } \\
\text { Tenn. }\end{array}$ & $\begin{array}{l}10 / 1 / 2001- \\
9 / 30 / 2008 *\end{array}$ & 0.16 & 7.97 & -14.42 & -0.37 & 0.99 & 0.92 \\
\hline 03575830 & Indian Creek near Madison, Ala. & $\begin{array}{l}10 / 1 / 1991- \\
9 / 30 / 2001\end{array}$ & 0.84 & 8.58 & -1.32 & 26.94 & 0.97 & 0.87 \\
\hline 03584600 & Elk River at Prospect, Tenn. & $\begin{array}{l}10 / 1 / 1984- \\
9 / 30 / 1994\end{array}$ & -6.13 & 2.23 & -12.12 & 10.96 & 0.97 & 0.93 \\
\hline 03588500 & Shoal Creek at Iron City, Tenn. & $\begin{array}{l}10 / 1 / 2001- \\
9 / 30 / 2008 *\end{array}$ & 5.08 & -2.16 & -11.79 & 13.52 & 0.96 & 0.87 \\
\hline 03592718 & $\begin{array}{l}\text { Little Yellow Creek East near } \\
\text { Burnsville, Miss. }\end{array}$ & $\begin{array}{l}10 / 1 / 1998- \\
9 / 30 / 2008\end{array}$ & -1.90 & 7.51 & -11.38 & 11.38 & 0.92 & 0.83 \\
\hline
\end{tabular}

\footnotetext{
* Stations that were calibrated for less than 10 years.
} 

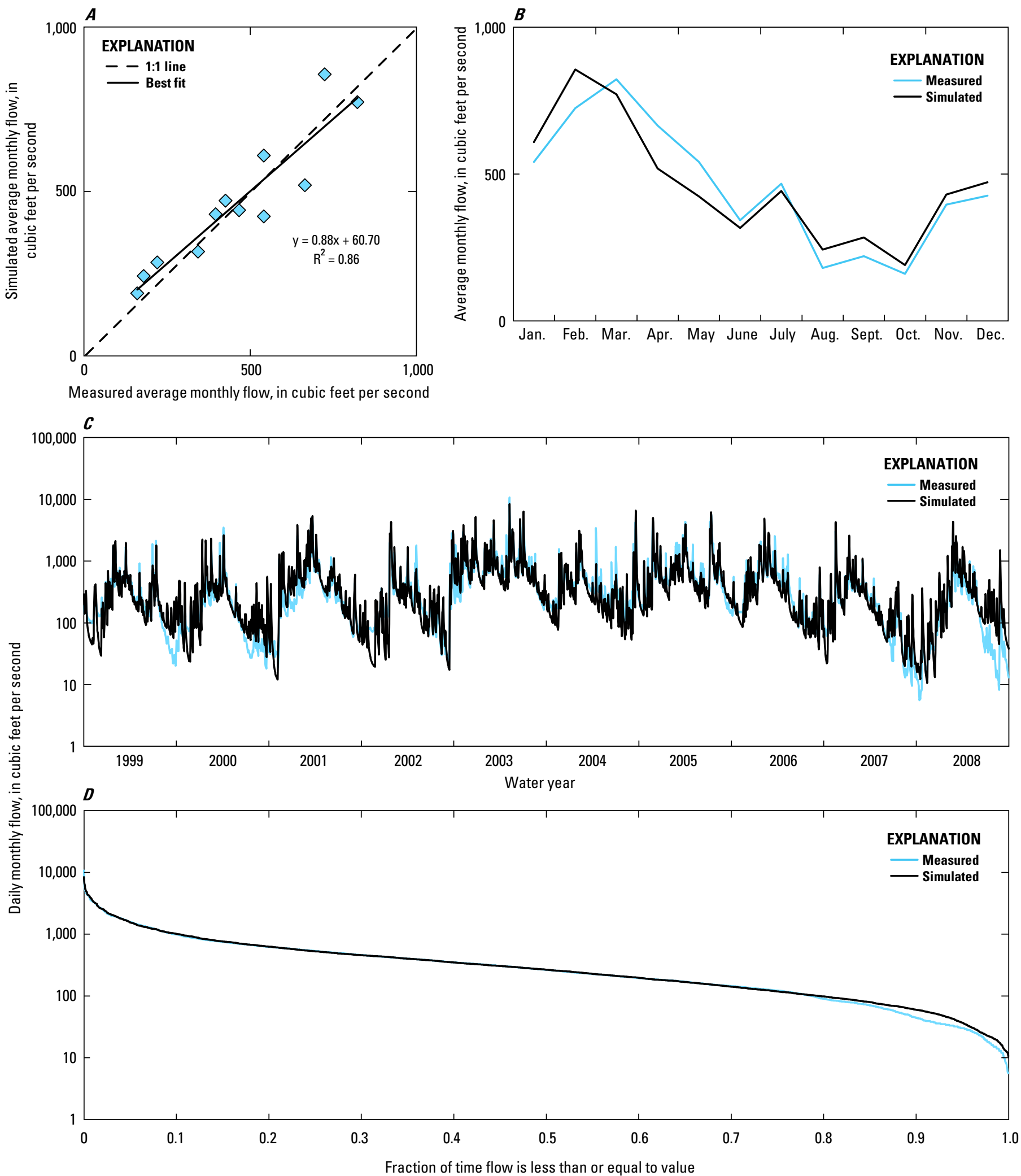

Figure 9. A, Best-fit line for simulated versus measured average monthly flow. $B$, Average monthly flow (1999-2008). C, Time series of daily flow (1999-2008). D, Duration curve of daily flow at the USGS station 02413000, Little Tallapoosa River at U.S. Route 27, at Carrollton, Ga. (1999-2008). 

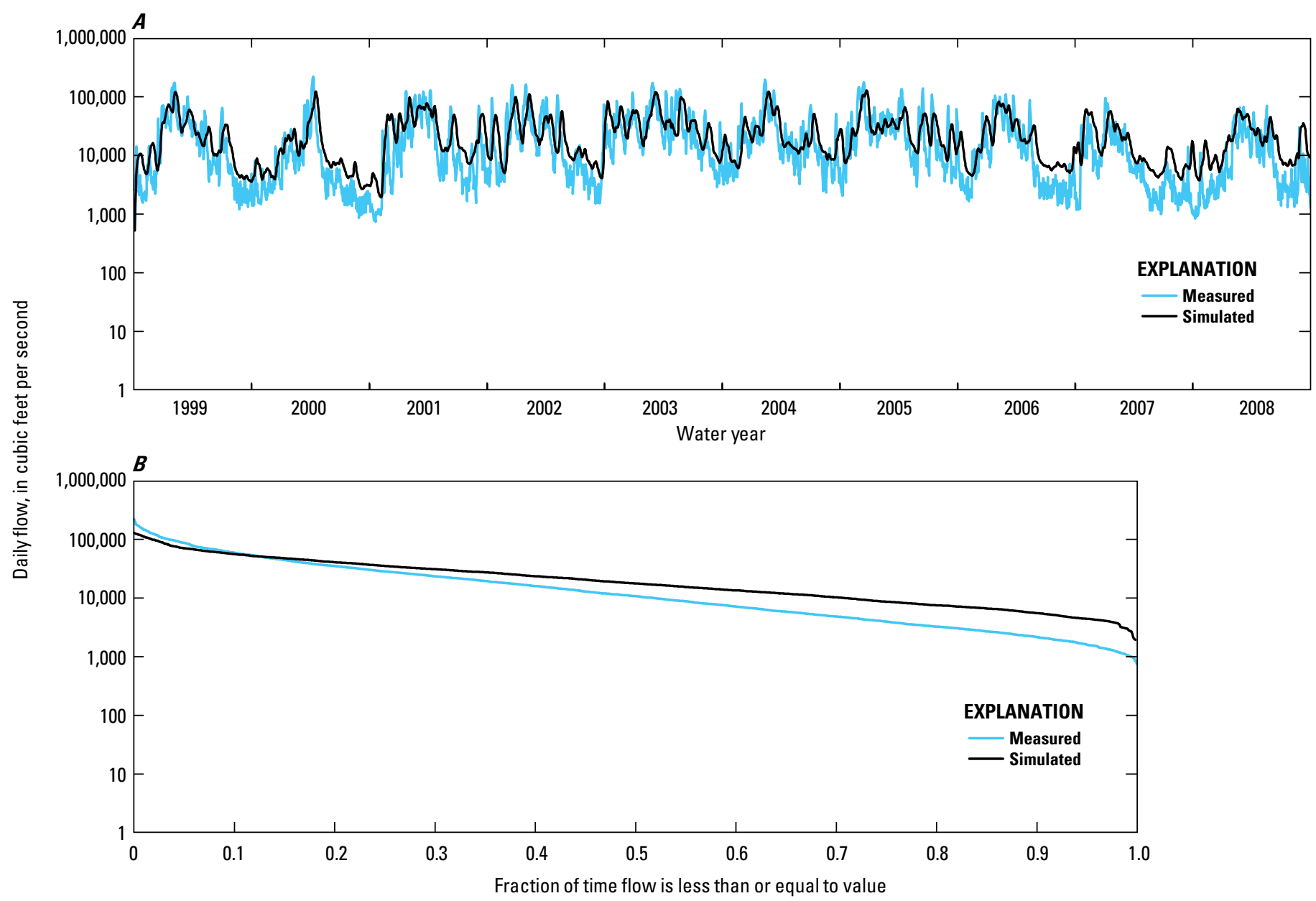

Figure 10. A, Time series of daily flow (1999-2008). B, Duration curve of daily flow at the USGS station 02467000, Tombigbee River at Demopolis Lock and Dam near Coatopa, Ala. (1999-2008).

\section{Summary}

In this study, four hydrologic models were developed for the Office of Water Resources in the Alabama Department of Economic and Community Affairs to determine an estimated amount of available water in the major river basins (Mobile River, Gulf of Mexico, Chattahoochee River, and Middle Tennessee River) that are within Alabama or that cross Alabama's borders. The Precipitation-Runoff Modeling System (PRMS) model was chosen because it can simulate basin response according to different precipitation scenarios and has already been applied successfully in the Southeastern United States. The PRMS model also includes a parameter-optimization calibration scheme that allows calibration to be optimized for a large number of stations and long periods of records. Based upon results from 90 calibration stations that compared simulated streamflow and flow volumes to recorded data from selected USGS streamflow gaging stations representing natural conditions, the models developed were considered to be a good representation of natural hydrology in Alabama because
71 calibration stations met target criteria. The four PRMS models were calibrated to estimate natural flows, with a focus on low flows. Seventy-one out of the 90 calibrated stations met target calibration criteria. Variability in the model performance can be attributed to limitations in correctly representing certain hydrologic conditions that are characterized by some of the ecoregions in Alabama. Ecoregions consisting of predominantly clayey soils and (or) low topographic relief yield less successful calibration reults whereas ecoregions consisting of loamy and sandy soils and (or) high topographic relief yield more successful calibration results. Study results indicate that the model does well in hilly regions with sandy soils because of rapid surface runoff and more direct interaction with subsurface flow. Given that $23,464 \mathrm{mi}^{2}$ out of $75,000 \mathrm{mi}^{2}$ were calibrated (approximately 30 percent) and the distribution of well-calibrated sites, the watershed models developed for the Alabama major river basins are considered to be valid planning tools that water-resource decisionmakers can use to evaluate the possible effects of different climate scenarios and changes in land and water use on water availability. 


\section{References Cited}

Atkins, J.B., 1998, National Water-Quality Assessment Program: Mobile River Basin: U.S. Geological Survey Fact Sheet FS-100-98, 4 p.

Atkins, J.B., Zappia, Humbert, Robinson, J.L., McPherson, A.K., Moreland, R.S., Harned, D.A., Johnston, B.F., and Harvill, J.S., 2004, Water quality in the Mobile River Basin, Alabama, Georgia, Mississippi, and Tennessee, 1999-2001: U.S. Geological Survey Circular 1231, 40 p.

Battaglin, William, Hay, Lauren, and Markstrom, Steve, 2011, Simulating the potential effects of climate change in two Colorado basins and at two Colorado ski areas: Earth Interactions, v. 15 , no. 22,23 p.

Duan, Qingyun, Sorooshian, Soroosh, and Gupta, V.K., 1994, Optimal use of the SCE-UA global optimization method for calibrating watershed models: Journal of Hydrology, v. 158, p. 265-284.

Hay, L.E., Markstrom, S.L., and Ward-Garrison, C., 2011, Watershed-scale response to climate change through the twenty-first century for selected basins across the United States: Earth Interactions, v. 15, no. 17, 37 p.

Hay, L.E., and Umemoto, Makiko, 2007, Multiple-objective step-wise calibration using Luca: U.S. Geological Survey Open-File Report 2006-1323, 25 p.

Homer, Collin, Huang, Chengquan, Yang, Limin, Wylie, Bruce, and Coan, Michael, 2004, Development of a 2001 national land-cover database for the United States: Photogrammetric Engineering and Remote Sensing, v. 70, p. 829-840.

Hutson, S.S., Littlepage, T.M., Harper, M.J., and Tinney, J.O., 2009, Estimated use of water in Alabama in 2005: U.S. Geological Survey Scientific Investigations Report 2009$5163,210 \mathrm{p}$

Johnson, G.C., Kidd, R.E., Journey, C.A., Zappia, Humbert, and Atkins, J.B., 2002, Environmental setting and waterquality issues of the Mobile River Basin, Alabama, Georgia, Mississippi, and Tennessee: U.S. Geological Survey WaterResources Investigations Report 02-4162, 120 p.

LaFontaine, J.H., Hay, L.E., Viger, R.J., Markstrom, S.L., Regan, R.S., Elliott, C.M., and Jones, J.W., 2013, Application of the Precipitation-Runoff Modeling System in the Apalachicola-Chattahoochee-Flint River Basin in the Southeastern United States: U.S. Geological Survey Scientific Investigations Report 2013-5162, 118 p.

Leavesley, G.H., Lichty, R.W., Troutman, B.M., and Saindon, L.G., 1983, Precipitation-Runoff Modeling System-User's manual: U.S. Geological Survey Water-Resources Investigations Report 83-4238, 207 p.
Leavesly, G.H., Restrepo, P.J., Markstrom, S.L., Dixon, M., and Stannard, L.G., 1996, The Modular Modeling System (MMS)_User's manual: U.S. Geological Survey Open-File Report 96-151, 200 p.

Lumb, A.M., McCammon, R.B., and Kittle, J.L., Jr., 1994, Users manual for an expert system (HSPEXP) for calibration of the Hydrological Simulation Program-Fortran: U.S. Geological Survey Water-Resources Investigations Report 94-4168, 102 p.

Markstrom, S.L., Niswonger, R.G., Regan, R.S., Prudic, D.E., and Barlow, P.M., 2008, GSFLOW-Coupled Groundwater and Surface-Water Flow Model based on the integration of the Precipitation-Runoff Modeling System (PRMS) and the Modular Ground-Water Flow Model (MODFLOW-2005): U.S. Geological Survey Techniques and Methods, book 6, chap. D1, 240 p.

Nash, J.E., and Sutcliffe, J.V., 1970, River flow forecasting through conceptual models, part I-A discussion of principles: Journal of Hydrology, v. 10, no. 3, p. 282-290.

Omernik, J.M., 1995, Ecoregions; A spatial framework for environmental management, in Davis, W.S., and Simon, T.P., eds., Biological assessment and criteria; Tools for water resource planning and decision making: Boca Raton, Fla., Lewis Publishers, p. 49-62.

Omernik, J.M., Griffith, G.E., and Clough, L.D., 2008, Ecoregions of Alabama and Georgia, in Cleveland, Cutler J., ed., Encyclopedia of Earth: Washington, D.C., Environmental Information Coalition, National Council for Science and the Environment.

Searcy, J.K., 1959, Flow-duration curves, manual of hydrology-Part 2. Low-flow techniques: U.S. Geological Survey Water-Supply Paper 1542-A, 33 p.

Soil Survey Staff, 2013, Natural Resources Conservation Service, United States Department of Agriculture: U.S. General Soil Map (STATSGO2), accessed June 21, 2013, at http:// soildatamart.nrcs.usda.gov.

Thornton, P.E., Thornton, M.M., Mayer, B.W., Wilhelmi, N., Wei, Y., and Cook, R.B., 2012, Daymet: Daily surface weather on a $1 \mathrm{~km}$ grid for North America, 1980-2008, accessed December 28, 2012, at http://daymet.ornl.gov/ from Oak Ridge National Laboratory Distributed Active Archive Center, Oak Ridge, Tenn. (Also available at http:// dx.doi.org/10.3334/ORNLDAAC/Daymet_V2.)

U.S. Census Bureau, 2011, The 2012 Statistical abstract of the United States (131st ed.), available at http://www.census. gov/compendia/statab/.

U.S. Geological Survey, 2007, Facing tomorrow's challenges-U.S. Geological Survey science in the decade 2007-2017: U.S. Geological Survey Circular 1309, 70 p.

Viger, R.J., Hay, L.E., Markstrom, S.L., Jones, J.W., and Buell, G.R., 2011, Hydrologic effects of urbanization and climate change on the Flint River Basin, Georgia: Earth Interactions, v. 15 , no. 20,25 p. 



\section{Appendix 1. Series of Graphs Presenting Model Results}

The following series of four graphs presents model results. Graph A is a best-fit line for simulated versus measured average monthly flow. Graph A also provides information about the $\mathrm{R}^{2}$, which statistically demonstrates how well the regression line fits for the data. Any $\mathrm{R}^{2}$ value above 0.5 indicates a good fit. Graph B demonstrates average monthly flows for simulated and measured flows. Graph C is a time series of daily flow of simulated and measured flows. Graph D is a duration curve of daily flow for the simulated and measured flows. The flow-duration curve is a cumulative frequency curve that shows the percentage of time during which specified flows were equaled or exceeded for the given period of analysis (Searcy, 1959).

[As separate files available for download at http://pubs.usgs.gov/sir/2014/5021/downloads/]

A1. USGS station 03568933, Lookout Creek near New England, Ga.

A2. USGS station 03574500, Paint Rock River near Woodville, Ala.

A3. USGS station 03575100, Flint River at Brownsboro, Ala.

A4. USGS station 03586500, Big Nance Creek at Courtland, Ala.

A5. USGS station 03571000, Sequatchie River near Whitwell, Tenn.

A6. USGS station 03575830, Indian Creek near Madison, Ala.

A7. USGS station 03584600, Elk River at Prospect, Tenn.

A8. USGS station 03588500, Shoal Creek at Iron City, Tenn.

A9. USGS station 03592718, Little Yellow Creek East near Burnsville, Miss.

A10. USGS station 02367310, Juniper Creek at State Highway 85 near Niceville, Fla.

A11. USGS station 02366996, Alaqua Creek near Pleasant Ridge, Fla.

A12. USGS station 02368000, Yellow River at Milligan, Fla.

A13. USGS station 02361500, Choctawatchee River near Bellwood, Ala.

A14. USGS station 02363000, Pea River near Ariton, Ala.

A15. USGS station 02371500, Conecuh River at Brantley, Ala.

A16. USGS station 02374500, Murder Creek near

Evergreen, Ala.

A17. USGS station 02479431, Pond Creek near Deer Park, Ala.

A18. USGS station 02479980, Crooked Creek near

Fairview, Ala.

A19. USGS station 02378500, Fish River near Silver Hill, Ala.

A20. USGS station 02370000, Blackwater River near Baker, Fla.

A21. USGS station 02362240, Little Double Bridges Creek near

Enterprise, Ala.

A22. USGS station 02372250, Patsaliga Creek near

Brantley, Ala.
A23. USGS station 02479945, Big Creek at County Road 63 near Wilmer, Ala.

A24. USGS station 02364570, Panther Creek near Hacoda, Ala.

A25. USGS station 02373000, Sepulga River near Mckenzie, Ala.

A26. USGS station 02479560, Escatawpa River near Agricola, Miss.

A27. USGS station 02365769, Bruce Creek at State Highway 81 near Redbay, Fla.

A28. USGS station 02374745, Burnt Corn Creek at State Highway 41 near Brewton, Ala.

A29. USGS station 02430085, Red Bud Creek near Moores Mill, Miss.

A30. USGS station 02438000, Buttahatchee River below Hamilton, Ala.

A31. USGS station 02442500, Luxapallila Creek at Millport, Ala.

A32. USGS station 02446500, Sipsey River near Elrod, Ala.

A33. USGS station 02448000, Noxubee River near Macon, Miss.

A34. USGS station 02450000, Mulberry Fork near Garden

City, Ala.

A35. USGS station 02450250, Sipsey Fork near Grayson, Ala.

A36. USGS station 02455000, Locust Fork near Cleveland, Ala.

A37. USGS station 02464000, North River near Samantha, Ala.

A38. USGS station 02464146, Turkey Creek near Tuscaloosa, Ala.

A39. USGS station 02467500, Sucarnoochee River at

Livingston, Ala.

A40. USGS station 02412000, Tallapoosa River near Heflin, Ala.

A41. USGS station 02381600, Fausett Creek near Talking Rock, Ga.

A42. USGS station 02384540, Mill Creek near Crandall, Ga.

A43. USGS station 02395120, Two Run Creek near Kingston, Ga.

A44. USGS station 02397410, Cedar Creek at GA Ave at

Cedartown, Ga.

A45. USGS station 02398300, Chattooga River above

Gaylesville, Ala.

A46. USGS station 02399200, Little River near Blue

Pond, Ala. 
A47. USGS station 02401000, Big Wills Creek near Reece City, Ala.

A48. USGS station 02401370, Big Canoe Creek near Springville, Ala.

A49. USGS station 02401470, Little Canoe Creek near Steele, Ala.

A50. USGS station 02405500, Kelly Creek near Vincent, Ala.

A51. USGS station 02424000, Cahaba River at Centreville, Ala.

A52. USGS station 02427250, Pine Barren Creek near Snow Hill, Ala.

A53. USGS station 02430615, Mud Creek near Fairview, Miss.

A54. USGS station 02450180, Mulberry Fork near Arkadelphia, Ala.

A55. USGS station 02450825, Clear Creek at New Hope Church near Poplar Springs, Ala.

A56. $A$, Best-fit line for simulated versus measured average USGS station 02413300, Little Tallapoosa River near Newell, Ala.

A57. USGS station 02382200, Talking Rock Creek near Hinton, Ga.

A58. USGS station 02430880, Cummings Creek near Fulton, Miss.

A59. USGS station 02453000, Blackwater Creek near Manchester, Ala.

A60. USGS station 02415000, Hillabee Creek near Hackneyville, Ala.

A61. USGS station 02388500, Oostanaula River near Rome, Ga.

A62. USGS station 02448900, Bodka Creek near Geiger, Ala.

A63. $A$, Best-fit line for simulated versus measured average USGS station 02456500, Locust Fork at Sayre, Ala.

A64. USGS station 02400100, Terrapin Creek at Ellisville, Ala. A65. USGS station 02464360, Binion Creek below Gin Creek near Samantha, Ala.

A66. USGS station 02401390, Big Canoe Creek at Ashville, Ala. A67. USGS station 02465493, Elliotts Creek at Moundville, Ala. A68. USGS station 02404400, Choccolocco Creek at Jackson Shoal near Lincoln, Ala.

A69. USGS station 02449245, Brush Creek near Eutaw, Ala.
A70. USGS station 02406500, Talladega Creek at Alpine, Ala.

A71. USGS station 02469800, Satilpa Creek near Coffeeville, Ala.

A72. USGS station 02408540, Hatchet Creek below Rockford, Ala.

A73. USGS station 02470072, Bassett Creek at US Highway 43 near Thomasville, Ala.

A74. USGS station 02419000, Uphapee Creek near Tuskagee, Ala.

A75. USGS station 02421000, Catoma Creek near Montgomery, Ala.

A76. USGS station 02422500, Mulberry Creek at Jones, Ala.

A77. USGS station 02427700, Turkey Creek at Kimbrough, Ala.

A78. USGS station 02471001, Chickasaw Creek near Kushla, Ala.

A79. USGS station 02331600, Chattahoochee River near Cornelia, Ga.

A80. USGS station 02333500, Chestatee River near Dahlonega, $\mathrm{Ga}$.

A81. USGS station 02337000, Sweetwater Creek near Austell, Ga.

A82. USGS station 02338523 , Hillabahatchee Creek at Thaxton Road, near Franklin, Ga.

A83. USGS station 02338660, New River at GA 100 near Corinth, Ga.

A84. USGS station 02338840, Yellowjacket Creek-Hammett Road below Hogansville, $\mathrm{Ga}$.

A85. USGS station 02339225, Wehadkee Creek below Rock Mills, Ala.

A86. USGS station 02341800, Upatoi Creek near Columbus, Ga.

A87. USGS station 02342500, Uchee Creek near Fort Mitchell, Ala.

A88. USGS station 02342933, South Fork Cowikee Creek near Batesville, Ala.

A89. USGS station 02343300, Abbie Creek near Haleburg, Ala. A90. USGS station 02343940, Sawhatchee Creek at Cedar Springs, Ga. 
For additional information regarding this publication, contact: USGS Alabama Water Science Center

AUM TechnaCenter

75 TechnaCenter Drive

Montgomery, AL 36117

Or visit the USGS Alabama Water Science Center Web site at: http://al.water.usgs.gov/

Edited and prepared by:

USGS Science Publishing Network

Raleigh and Reston Publishing Service Centers 


\section{曾}

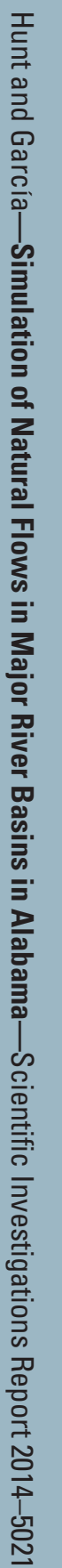

